\title{
Cutaneous Manifestations of COVID-19: A Systematic Review
}

\author{
Harjas Singh, ${ }^{1}$ Harleen Kaur, ${ }^{2}$ \\ Kanhaiya Singh, ${ }^{1,3}$ and Chandan K. Sen ${ }^{1,3, *}$ \\ ${ }^{1}$ Indiana University School of Medicine, Indianapolis, Indiana, USA. \\ ${ }^{2}$ Department of Medicine, Indiana University School of Medicine, Indianapolis, Indiana, USA. \\ ${ }^{3}$ Department of Surgery, Indiana University Health Comprehensive Wound Center, and Indiana Center for Regenerative \\ Medicine, Indiana University School of Medicine, Indianapolis, Indiana, USA.
}

Objective: Coronavirus disease 2019 (COVID-19), caused by severe acute respiratory syndrome coronavirus 2 (SARS-CoV-2), is currently a pandemic. Although pulmonary health has been the primary focus of studies during the early days of COVID-19, development of a comprehensive understanding of this emergent disease requires knowledge of all possible disease manifestations in affected patients. This Preferred Reporting Items for Systematic Reviews and Meta-Analyses (PRISMA)-compliant review focuses on cutaneous manifestations reported in COVID-19 patients.

Approach: Literature review was conducted using the PubMed database to examine various cutaneous manifestations related to the SARS-CoV-2 infection. Published articles $(n=56)$ related to search criteria from the onset of the COVID-19 pandemic to June 30, 2020, were included. The primary literature articles included in this study were mainly from France, Spain, Italy, and the United Kingdom.

Results: Unique to many other symptoms of COVID-19, its cutaneous manifestations have been found in people of all age groups, including children. The cutaneous manifestations of COVID-19 are varied and include maculopapular, chilblain-like, urticarial, vesicular, livedoid, and petechial lesions. In addition, rashes are common in multisystem inflammatory syndrome in children, a new and serious health condition that shares symptoms with Kawasaki disease and is likely related to COVID-19. In addition, personal protective equipmentrelated skin wounds are of serious concern since broken cutaneous barriers can create an opening for potential COVID-19 infections.

Innovation and Conclusion: As this virus continues to spread silently, mainly through asymptomatic carriers, an accurate and rapid identification of these cutaneous manifestations may be vital to early diagnosis and lead to possible better prognosis in COVID-19 patients. This systematic review and photo atlas provide a detailed analysis of the skin pathologies related to COVID-19. Study of these cutaneous manifestations and their pathogenesis, as well their significance in human health will help define COVID-19 in its entirety, which is a prerequisite to its effective management.

Keywords: wound, skin lesions, COVID-19, maculopapular, chilblain-like, MIS-C
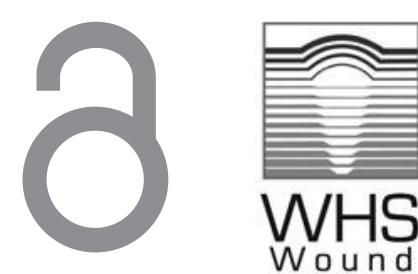

Wound

Healing

Society

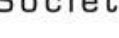
(1) 


\section{SCOPE AND SIGNIFICANCE}

CutANEOUS MANIFESTATIONS HAVE been increasingly reported in association with the coronavirus disease 2019 (COVID-19) pandemic. Despite an increase in relevance, much remains unknown concerning the characterization, incidence, and pathogenesis of these dermatological symptoms. This Preferred Reporting Items for Systematic Reviews and Meta-Analyses (PRISMA)-compliant systematic review provides a detailed analysis on the changes in skin morphology related to COVID-19 and discusses plausible underlying molecular mechanisms. Furthermore, this review discusses cutaneous complications associated with personal protective equipment (PPE) and their potentially serious consequences. Study of these cutaneous manifestations and their pathogenesis, as well as their significance in human health will help define COVID-19 in its entirety, which is a prerequisite to its effective management.

\section{TRANSLATIONAL RELEVANCE}

This work is directly translationally relevant because it reviews critical evidence primarily originating from COVID-19 patients. Given that the report is presented at the time when the pandemic is ongoing, it is expected that the content will provide both health care providers as well as researchers with critical insight helpful to improve disease management. In addition, this article will help construct novel experimental hypotheses for future research.

\section{CLINICAL RELEVANCE}

COVID-19's cutaneous symptoms appear in patients of all ages with differing levels of severity. Currently, the importance of these symptoms remains relatively unknown by many health care personnel due to a shortage of literature reviews. This review consolidates available data and summarizes information of each skin manifestation, including their incidence, susceptible age groups, location of lesions, severity, and time of onset relative to other COVID-19 clinical symptoms. An increase in awareness and identification of these cutaneous manifestations by physicians may be vital to an earlier and more accurate diagnosis, possibly resulting in better prognosis in COVID-19 patients.

\section{INTRODUCTION}

COVID-19, caused by severe acute respiratory syndrome coronavirus 2 (SARS-CoV-2), is a re- spiratory tract infection that has rapidly spread worldwide since its first identification in Wuhan, China, during December of 2019., ${ }^{1,2}$ The asymptomatic transmission, high infection rate, and high mortality rate among the elderly and immunocompromised associated with this disease led the World Health Organization to declare it as a pandemic in March 2020. As of early August 2020 , in excess of 20 million cases of COVID-19 have been confirmed globally with more than 750,000 deaths reported in over 200 countries and territories.

SARS-CoV-2 is a novel enveloped, positivesense, single-stranded RNA virus that is part of the genus Betacoronavirus. ${ }^{1}$ Angiotensin-converting enzyme 2 (ACE2) is a protein that functions as the sole receptor for SARS-CoV-2 to invade cells and cause infection in humans. ${ }^{3}$ Although this virus primarily attacks the respiratory tract, $A C E 2$ gene expression has been discovered in several human tissues, including gastrointestinal and skin tissue. ${ }^{3}$ In a recent analysis of 31 Genotype-Tissue Expression human tissue, Li et al. ${ }^{3}$ have found that among human organs, small intestine, testis, kidneys, heart, thyroid, and adipose tissue have the highest ACE2 expression levels, while blood, spleen, bone marrow, brain, blood vessels, and muscle have the lowest ACE2 expression levels.

Other organs like lungs, colon, liver, bladder, and adrenal glands have medium expression of ACE2 in the human body. ${ }^{3}$ To investigate whether skin was a potential target for SARS-CoV-2 infection, Xue et $a l .^{4}$ analyzed datasets available in public domain (GEPIA2 and ARCHS4) to explore ACE2 mRNA expression and ACE2-positive cell composition in skin tissues. The expression of ACE2 was significantly higher in keratinocytes than other cellular compartments in skin tissues, such as fibroblasts and melanocytes. ${ }^{4}$ This was further validated through independent single-cell RNA-seq data in which Xue et al. ${ }^{4}$ have found that out of all ACE2-positive cells in skin, keratinocytes account for $97.37 \%$ followed by sweat gland cells that account for $2.63 \%$. The widespread expression of ACE2 suggests that this virus might be responsible for infecting other human tissues alongside the lungs, and could potentially result in additional clinical manifestations. ${ }^{3,4}$

COVID-19 has a high infectivity rate, primarily due to its spread through respiratory droplets. After an incubation period of 1-14 days, common clinical symptoms such as "fever, cough, fatigue, sputum production, shortness of breath, sore throat, and headache" begin to appear. ${ }^{1}$ In addition to these common symptoms, novel symptoms such 
as a variety of cutaneous manifestations have been reported worldwide. ${ }^{5}$ Early data from China reported skin symptoms were present in only $0.2 \%$ of 1,099 confirmed COVID-19 cases. ${ }^{6}$ However, data from Italy later revealed a higher percentage with skin manifestations present in $20.4 \%$ of 88 positive COVID-19 patients. ${ }^{5}$ Despite differences in prevalence, reports of cutaneous lesions have become increasingly common in many age groups, including children who were once thought to be asymptomatic to the infection. Although not much is known concerning the pathophysiologic mechanisms of these cutaneous manifestations, their identification may be vital to early diagnosis and lead to possible better prognosis in COVID-19 patients. This systematic review provides a detailed analysis on the changes in skin morphology related to COVID-19 and the possible molecular mechanisms and health significance underlying these cutaneous manifestations.

\section{METHODS}

Literature review was conducted using the PubMed database to examine various cutaneous manifestations related to the SARS-CoV-2 infection. Published articles related to search criteria from the onset of the COVID-19 pandemic to June 30, 2020, were included. Search strategy included "COVID-19," "coronavirus," or "SARS-CoV-2" in combination with relevant terminology such as "skin," "cutaneous," "chilblain-like," " maculopapular," "urticarial," "livedo," "vesicular," "petechiae," and "multisystem inflammatory syndrome." Cases series including five or more patients were selected for this review. Individual case reports were excluded from the table data; however, may have been used during analysis of various skin rashes. In total, 56 articles complied with search criteria and were used for data collection (Fig. 1).

Two authors (H.S. and H.K.) worked independently, searched, and scanned all abstracts and titles in duplicate to identify articles relevant to this study. When discrepancies occurred, a third reviewer (K.S.) made the final judgment. Singh and Kaur assessed eligibility from full-text articles, with a similar process for potential disagreements as described above. Data extraction from included studies (i.e., published abstracts and articles) was duplicated with a standardized extraction form. The characteristics of the research (study design, antiviral regimen, therapy duration, etc.), the outcomes of interest mentioned above, and biased risk assessment were extracted. The source of the data presented in this review article was from published papers available in public domain hence IRB approval was not needed.

\section{RESULTS}

Cutaneous manifestations associated with COVID-19 infection are numerous and can vary greatly when compared to one another. The six central dermatological patterns of COVID-19 are described as maculopapular/morbilliform, urticarial, vesicular, chilblain like, petechiae/purpura, and livedoid. These clinical findings can be further classified as either inflammatory (maculopapular/ morbilliform, urticarial, and vesicular) or vascular lesions (chilblain-like, petechiae/purpura, and livedoid). ${ }^{7}$ Due to scientific need for appropriate classification of these cutaneous manifestations, an algorithm has been published to provide for easier classification of the main COVID-19 skin findings mentioned earlier. ${ }^{8}$ Finally, multisystem inflammatory syndrome in children (MIS-C), a novel illness thought to be related to COVID-19, can also present with dermatological symptoms, although clarification of their cutaneous classifications is needed.

\section{Maculopapular/morbilliform lesions}

Maculopapular lesions are amongst the most prevalent cutaneous manifestations seen throughout the COVID-19 pandemic (Table 1) are maculopapular lesions. These lesions are frequently the result of adverse drug reactions or viral infections. ${ }^{9}$ Maculopapular lesions occurring in children are typically the result of viral infections, whereas drug eruptions are usually the trigger for these lesions in adults $^{10}$ (Fig. 2).

A case series of 375 patients with skin lesions associated with COVID-19 identified a $47 \%$ prevalence of maculopapular lesions. ${ }^{11}$ Prevalence of these lesions has varied among studies with a smaller number of cases, ranging from $5 \%$ to $70 \%$. Many of the maculopapular rashes reported were observed in middle-aged or elderly patients ${ }^{11-14}$; however, cases have appeared in younger adults. ${ }^{15}$ Anatomically, the majority of these lesions were located on the trunk of the body. ${ }^{12,13,15-18}$ Despite a large case series from Spain reporting simultaneous onset of many maculopapular lesions with COVID-19's systemic symptoms, ${ }^{11}$ other studies had noticed a later onset in their smaller patient populations. ${ }^{12-14,19}$ Studies with a later onset of cutaneous manifestations reported average latency times of 27.6 days and 27.85 days. ${ }^{12,13}$ Mean duration of the exanthems ranged from 8.6 to 11.6 days. ${ }^{11-13}$ According to one case series, pruritus was present in $56 \%$ of patients with maculo- 


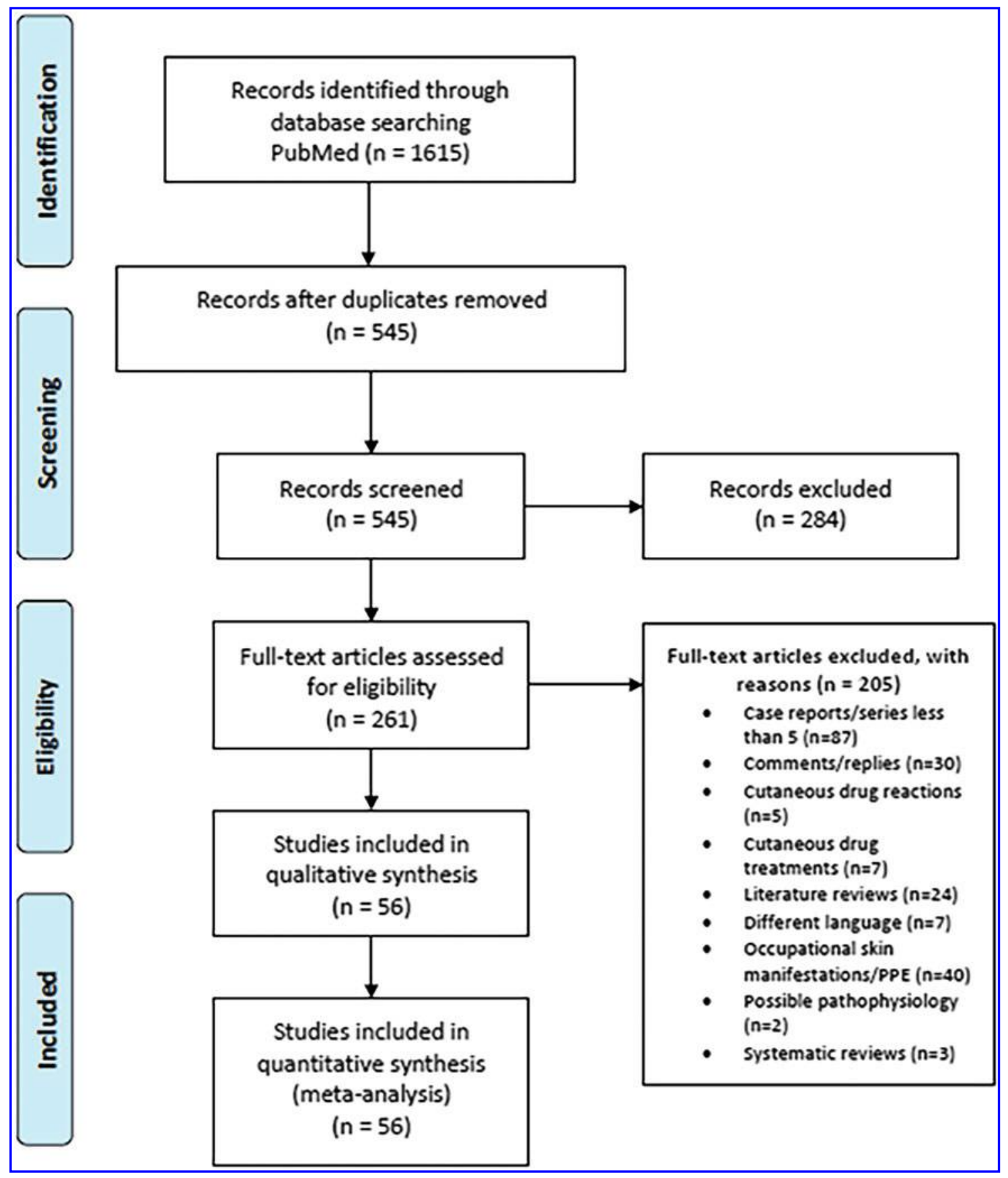

Figure 1. The PRISMA statement of this review. PRISMA, Preferred Reporting Items for Systematic Reviews and Meta-Analyses. Source: Moher D, Liberati A, Tetzlaff J, Altman DG. Preferred reporting items for systematic reviews and meta-analyses: The PRISMA statement. The PRISMA Group. PLoS Med 6:e1000097.

papular lesions. Interestingly, the same study suggested that maculopapular rashes are associated with greater severity of COVID-19 infections; this was supported by a $2 \%$ mortality rate reported in patients with these lesions. ${ }^{11}$ Histopathological findings for these lesions are dependent on the time of onset. ${ }^{14}$ Early-onset rashes are presented with moderate epidermal spongiosis and perivascular lymphocytic infiltrate with eosinophils in the dermal region. ${ }^{14}$ Contrastingly, histology of late-onset lesions exhibited perivascular lymphocytic infiltrate and histiocytes among collagen fibers. These late-onset lesions are devoid of mucin deposits. ${ }^{14}$ Additional examination by Reymundo et al. reported presence of mild superficial perivascular lymphocytic infiltrate in skin biopsies. ${ }^{13}$

There have been a few theories discussed concerning the molecular mechanisms of maculopapular lesions. Galván Casas et al. described these lesions as unhelpful toward diagnosis due to 
Table 1. Demographic and clinical details of maculopapular rashes observed in COVID-19 patients

\begin{tabular}{|c|c|c|c|c|}
\hline $\begin{array}{l}\text { Article } \\
\text { and Year }\end{array}$ & $\begin{array}{c}\text { Number of Patients, } \\
\text { Age, Gender }\end{array}$ & $\begin{array}{l}\text { Suspected or Confirmed } \\
\text { COVID-19 }\end{array}$ & $\begin{array}{l}\text { COVID-19 Cutaneous } \\
\text { Manifestations }\end{array}$ & $\begin{array}{c}\text { Anatomical Location } \\
\text { of Cutaneous Manifestations }\end{array}$ \\
\hline $\begin{array}{l}\text { Askin } \\
\quad \text { et al. }(2020)^{16}\end{array}$ & $\begin{array}{l}\text { Total population: } 210 \text { patients } \\
\text { Male age, mean: } \\
57.44 \pm 17.259 \text { years } \\
\text { Female age, mean: } \\
58.80 \pm 15.918 \text { years } \\
123 \text { male }(58.6 \%), 87 \text { female }(41.4 \%) \\
\text { Skin lesions: } 52 / 210(24 \%) \text { : } \\
33 \text { male }(26.8 \%), 19 \text { female }(21.8 \%) \\
\text { Maculopapular: } 12 / 52(23 \%)\end{array}$ & $\begin{array}{l}\text { SARS-CoV-2 PCR in total population, } \\
\text { PCR performed in } 158 \text { patients: } \\
\text { Positive: } 88 / 158(55.7 \%) \\
\text { Negative: } 70 / 158(44.3 \%) \\
\text { SARS-CoV-2 PCR in } 52 \text { patients } \\
\text { with cutaneous findings: } \\
\text { Positive: } 34 / 52(65.4 \%) \\
\text { Negative: } 18 / 52(34.6 \%)\end{array}$ & $\begin{array}{l}\text { Classification of } 52 \text { patients with } \\
\text { skin lesions: } \\
\text { Erythematous scaly rash } \\
(n=17,32.7 \%) \\
\text { Maculopapular rash }(n=12,23 \%) \\
\text { Urticarial lesions }(n=7,3.5 \%) \\
\text { Petechial purpuric rash }(n=4,7.7 \%) \\
\text { Necrosis }(n=4,7.7 \%) \\
\text { Enanthema, aphthous stomatitis } \\
(n=3,5.8 \%) \\
\text { Vesicular rash }(n=3,5.8 \%) \\
\text { Pernio }(n=1,1.9 \%)\end{array}$ & $\begin{array}{l}\text { Most maculopapular lesions } \\
\text { were located on trunk; } \\
\text { in one case, lesion was } \\
\text { present on the extremities. }\end{array}$ \\
\hline $\begin{array}{l}\text { Dalal } \\
\qquad \text { et al. }(2020)^{27}\end{array}$ & $\begin{array}{l}\text { Total population: } 102 \text { patients } \\
\text { Age, mean (SD): } 39.30 \\
\text { years (SD 17.9) } \\
95 \text { male }(93.1 \%), 7 \text { female }(6.9 \%) \\
\text { Skin lesions: } 13 / 102(12.7 \%) \\
\text { Maculopapular: } 3 / 13(23.1 \%)\end{array}$ & $\begin{array}{l}\text { SARS-CoV-2 PCR: } \\
\text { Positive: 102/102 (100\%) }\end{array}$ & $\begin{array}{l}\text { Classification of } 13 \text { patients with } \\
\text { skin lesions: } \\
\text { Maculopapular rash }(n=3,23.1 \%) \\
\text { Urticarial lesions }(n=2,15.4 \%) \\
\text { Pruritis without specific } \\
\quad \text { cutaneous signs } \\
(n=8,69.2 \%)\end{array}$ & $\begin{array}{l}\text { Location of maculopapular } \\
\text { lesions: } \\
\text { Trunk }(n=3) \\
\text { Extremities }(n=1) \\
\text { Maculopapular rash presented } \\
\text { in centripetal distribution }\end{array}$ \\
\hline $\begin{array}{l}\text { de Masson } \\
\text { et al. }(2020)^{15}\end{array}$ & $\begin{array}{l}\text { Total population: } 277 \text { patients } \\
\text { Age, mean (range): } 27 \text { years (2-98) } \\
\text { "Half of patients were male" } \\
\text { Skin lesions: } 277 / 277(100 \%) \\
\text { Morbilliform: } 25 / 277(9 \%) \\
\quad \text { Age, median (range): } 29 \text { years }(2-70) \\
\quad 10 \text { male }(48 \%), 11 \text { female }(52 \%)\end{array}$ & $\begin{array}{l}\text { SARS-CoV-2 PCR in } 34 \\
\text { patients (12\%): } \\
\text { Positive: } 25 / 34(73.5 \%) \\
\text { Negative: } 9 / 34(26.5 \%)\end{array}$ & $\begin{array}{l}\text { Classification: } \\
\text { Morbilliform lesions }(n=25,9 \%) \\
\text { Acral lesions }(n=142,51 \%) \\
\text { Vesicular lesions }(n=41,15 \%) \\
\text { Livedo reticularis }(n=4,1 \%) \\
\text { Urticarial lesions }(n=26,9 \%) \\
\text { Petechial lesions }(n=7,3 \%) \\
\text { Other types of lesions }(n=41,15 \%)\end{array}$ & $\begin{array}{l}\text { Location of morbilliform } \\
\text { lesions: } \\
\text { Trunk and limbs } \\
(n=25,100 \%) \\
\text { Face }(n=2,8 \%)\end{array}$ \\
\hline $\begin{array}{l}\text { Docampo-Simon } \\
\text { et al. }(2020)^{35}\end{array}$ & $\begin{array}{l}\text { Total population: } 58 \text { patients } \\
\text { Age, median (range): } 14 \text { years } \\
\text { ( } 3 \text { months-85 years) } \\
29 \text { male }(50 \%), 29 \text { female }(50 \%) \\
\text { Skin lesions: } 58 / 58(100 \%) \\
\text { Maculopapular: } 3 / 58(5.17 \%)\end{array}$ & $\begin{array}{l}\text { SARS-CoV-2 PCR in } 39 \\
\text { patients }(67 \%) \text { : } \\
\text { Positive: } 1 / 39(2.56 \%) \\
\text { Negative: } 38 / 39(97.4 \%)\end{array}$ & $\begin{array}{l}\text { Classification: } \\
\text { Chilblain-like lesions }(n=42) \\
\text { Purpuric }(n=3) \\
\text { Maculopapular }(n=3) \\
\text { Vesiculobullous }(n=3) \\
\text { Eczematous }(n=3) \\
\text { Paronychia }(n=2) \\
\text { Ulcer }(n=1) \\
\text { Desquamation }(n=1)\end{array}$ & $\begin{array}{l}\text { Location of ALL lesions: } \\
\text { Hands }(n=9,15.5 \%) \\
\text { Feet }(n=36,62.1 \%) \\
\text { Hands and Feet } \\
(n=13,22.4 \%)\end{array}$ \\
\hline $\begin{array}{l}\text { Herrero-Moyano } \\
\text { et al. }(2020)^{12}\end{array}$ & $\begin{array}{l}\text { Total population: } 1,177 \text { patients } \\
\text { Skin lesions: } 8 / 1,177(0.7 \%) \\
\text { Maculopapular: } 8 / 8(100 \%) \\
\text { Age, mean (range): } 72.2 \\
\text { years }(51-88) \\
4 \text { male }(50 \%), 4 \text { female }(50 \%)\end{array}$ & $\begin{array}{l}\text { SARS-CoV-2 PCR in } 8 \text { patients } \\
\text { with cutaneous findings: } \\
\text { Positive: } 7 / 8(87.5 \%) \\
\text { Negative: } 1 / 8(12.5 \%)\end{array}$ & $\begin{array}{l}\text { Classification: } \\
\text { III-defined erythematous patches } \\
\text { to coalescent maculopapules, } \\
\text { some with violaceous center; } \\
\text { one patient developed pustules } \\
\text { and desquamation }\end{array}$ & $\begin{array}{l}\text { Location of morbilliform lesions: } \\
\text { Trunk }(n=7) \\
\text { Flexures }(n=4) \\
\text { Proximal extremities }(n=2) \\
\text { Face }(n=2) \\
\text { Generalized }(n=1)\end{array}$ \\
\hline $\begin{array}{l}\text { Reymundo } \\
\quad \text { et al. }(2020)^{13}\end{array}$ & $\begin{array}{l}\text { Total population: } 18 \text { patients } \\
\text { Skin lesions: } 7 / 18(38.9 \%) \\
\text { Maculopapular: } 7 / 7(100 \%) \\
\text { Age, mean (range): } \\
66.57 \text { years (57-82) } \\
2 \text { male }(28.6 \%), 5 \text { female }(71.4 \%)\end{array}$ & $\begin{array}{l}\text { SARS-CoV-2 PCR: } \\
\text { Positive: 18/18 (100\%) }\end{array}$ & $\begin{array}{l}\text { Classification: } \\
\quad \text { Maculopapular eruptions }\end{array}$ & $\begin{array}{l}\text { Location of morbilliform lesions: } \\
\text { Involvement of the } \\
\text { trunk }(n=7) \\
\text { Proximal upper limb } \\
\text { involvement }(n=6) \\
\text { Lower limb involvement }(n=1)\end{array}$ \\
\hline $\begin{array}{l}\text { Rubio-Muniz } \\
\quad \text { et al. }(2020)^{14}\end{array}$ & $\begin{array}{l}\text { Total population: } 34 \text { patients } \\
\text { Age, median (range): } \\
54.5 \text { years (31-66) } \\
14 \text { male }(41 \%), 20 \text { female }(59 \%) \\
\text { Skin lesions: } 34 / 34(100 \%) \\
\text { Maculopapular: } 10 / 34(29.4 \%) \\
\text { Age, median (range): } \\
53 \text { years (31-61) } \\
4 \text { male }(40 \%), 6 \text { female }(60 \%)\end{array}$ & $\begin{array}{l}\text { COVID-19 diagnosis (total population): } \\
\text { Positive PCR: 17/34 (50\%) } \\
\text { Positive radiology: } 8 / 24(23.5 \%) \\
\text { Negative PCR: } 9 / 34 \text { (26.5\%) } \\
\text { COVID-19 diagnosis (maculopapular): } \\
\text { Positive PCR: 6/10 (60\%) } \\
\text { Positive radiology: } 3 / 10(30 \%) \\
\text { Negative PCR: } 1 / 10(10 \%)\end{array}$ & $\begin{array}{l}\text { Classification: } \\
\text { Maculopapular }(n=10) \\
\text { Pseudo-chilblain }(n=9) \\
\text { Targetoid lesions }(n=5) \\
\text { Palpable purpura }(n=4 \text {, of which } \\
2 \text { cases are with vesicular lesions) } \\
\text { Acute urticaria ( } n=3) \\
\text { Vesicular ( } n=2 \text {, these also have } \\
\text { palpable purpura) } \\
\text { Remaining } 3 \text { cases include livedo } \\
\text { reticularis, urticarial exanthem, } \\
\text { and prurigo lesions. }\end{array}$ & N/A \\
\hline
\end{tabular}




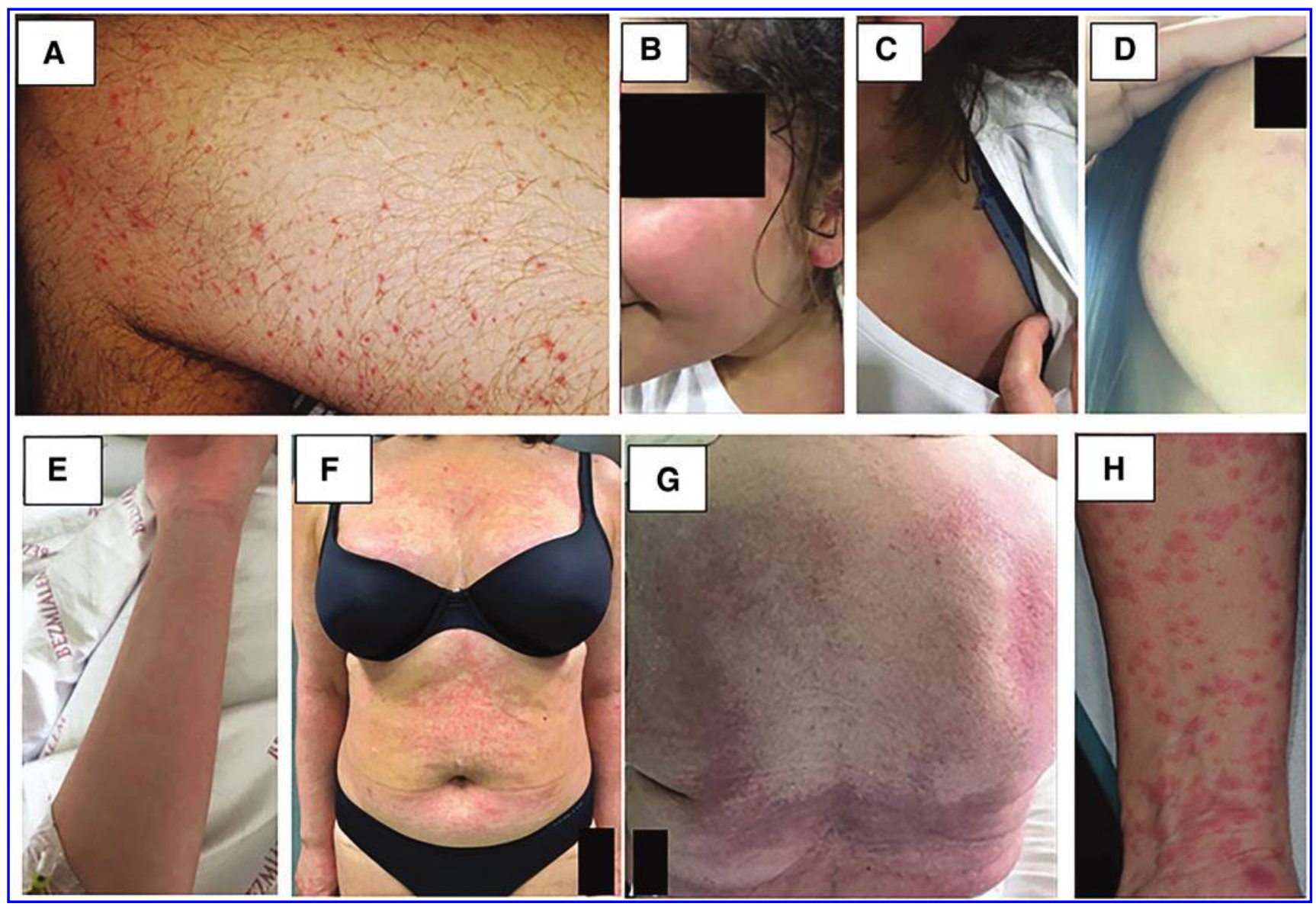

Figure 2. Examples of maculopapular rash seen in COVID-19-positive patients. (A) Maculopapular lesions, a few of which present with a perifollicular distribution, located on the thigh of patient. (B, C) Eleven-year-old child with COVID-19 presenting with pruritis and maculopapular lesions located on her face and shoulder. Duration of lesions was 5 days. (D, E) Seventeen-year-old adolescent with COVID-19 presenting with a maculopapular rash and mild pruritis only after receiving HCO treatment, suggesting a drug-induced exanthema. (F) Nonspecific maculopapular rash located on the trunk of recovering COVID-19 patient. (G) Maculopapular rash appearing on posterior trunk of a confirmed COVID-19 patient. (H) Maculopapular lesions described as small plaques after fusion of lesions. COVID-19, Coronavirus Disease 2019. Reproduced with permission from John Wiley and sons (A-G); Wolters Kluwer Health, Inc. (H). The following original reports are credited: Galván Casas et al. ${ }^{11}$; Duramaz et al. ${ }^{19}$; Rubio-Muniz et al..$^{14}$; Gianotti et al. ${ }^{18}$

the potential cause of adverse drug reactions. This is plausible as patients with these rashes had more severe infections and therefore received greater drug therapy. ${ }^{11}$ Potential drugs given against COVID-19 such as Ribavirin, Colchicine, intravenous immunoglobulin (IVIG) treatments, Lopinavir, Ritonavir, and other antiretroviral drugs are known to result in cutaneous side effects similar to maculopapular and morbilliform rashes. ${ }^{20}$ However, maculopapular eruptions have been observed in case series with no new medications taken, suggesting that these lesions may not solely be drug related. ${ }^{13}$ Finally, Herrero-Moyano et al. proposed a hypothesis that a cytokine storm produced by a hyperactive immune system could be the instigator behind these rashes after observing late-onset maculopapular eruptions. ${ }^{12}$ Other significant hypotheses about the potential causes of maculopapular lesions have been provided in Table 9.

\section{Urticarial lesions}

In addition to maculopapular rash, urticarial lesions have also been noted in several COVID-19 case series. These lesions typically present as hives or angioedema and can be characterized as an erythematous slightly raised papular rash followed by intense pruritic sensations. ${ }^{21}$ Although considered one of COVID-19's most frequent cutaneous manifestations, urticarial lesions have been a relatively common dermatological condition even before the pandemic. Acute urticaria, defined as a self-limiting lesion lasting less than 6 weeks, has been reported to affect $20 \%$ of the general population. ${ }^{22}$ Meanwhile, chronic urticaria, described as a recurring lesion present for greater than 6 weeks, 
appears to affect $5 \%$ of the general population. ${ }^{22}$ Common triggers include viral/bacterial/parasitic infections, environmental exposures, and immunoglobulin E-mediated allergic reactions in response to medications, food, or biting/stinging insects. ${ }^{22}$ Urticarial lesions typically resolve after removal of the offending agent; however, in severe cases, the use of antihistamines and steroids has been implemented for symptomatic relief (Fig. 3).

Acute urticarial lesions have been discussed in several COVID-19 studies $^{11,14,16,20,23-26}$ (Table 2). Prevalence of these lesions among other skin

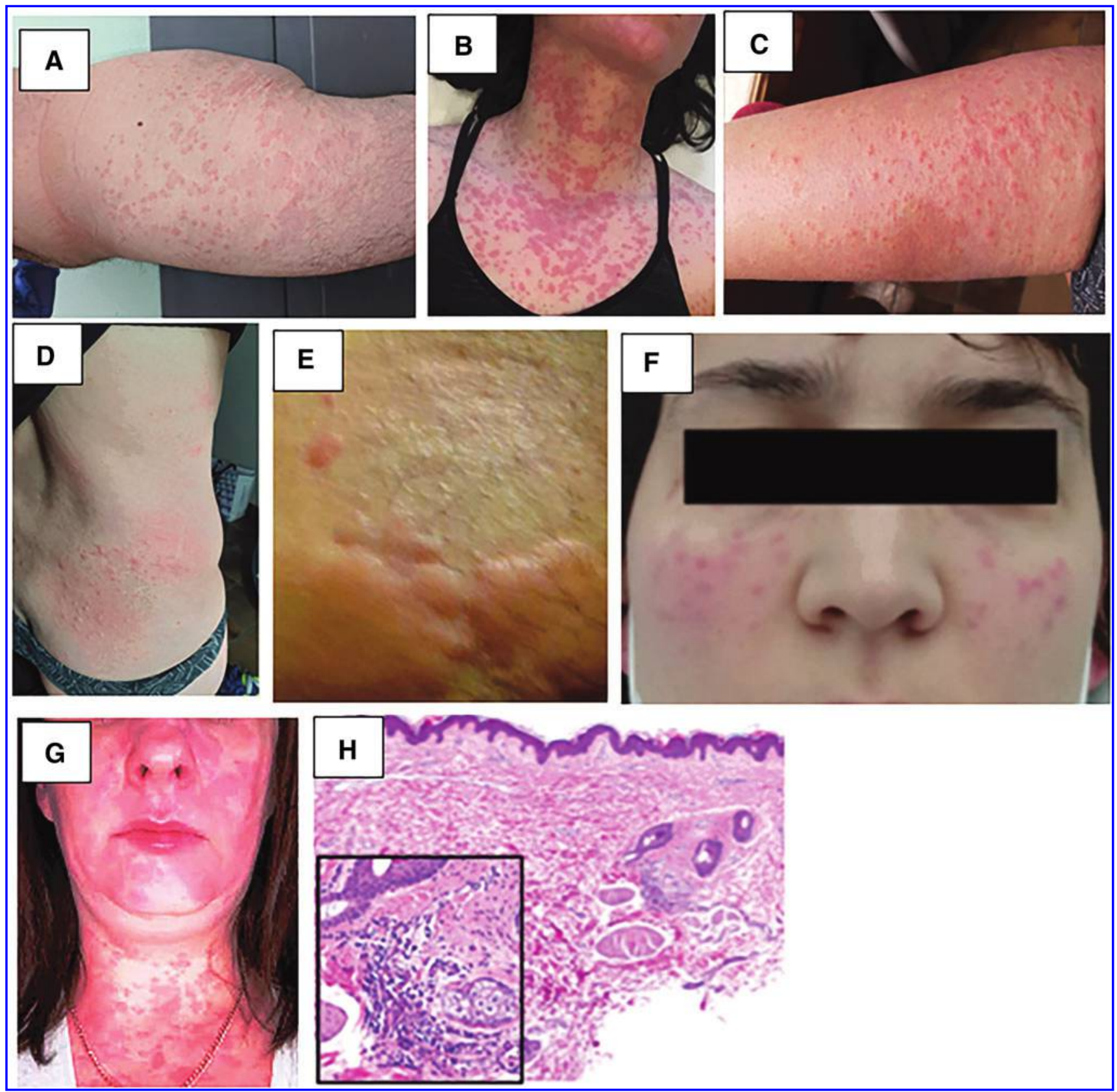

Figure 3. Examples of urticarial rash seen during the COVID-19 pandemic. (A) Urticarial lesions dispersed along buttocks and proximal lower extremity (thigh). (B) Urticarial rash, similar to hives, appearing on patient's neck and chest. (C, D) Thirty-nine-year-old nurse presenting with generalized pruritic urticarial rash 2 days before the onset of pyrexia, chills, myalgia, and headache. Lesions were located on her thigh (C) and back (D). (E) Generalized pruritic urticaria present on elderly man with COVID-19 infection. (F) Thirty-two-year-old female presenting with a dispersed urticarial rash on her face, trunk, and lower limbs. Lesion onset was 6 days after first COVID-19 clinical symptoms and lesion duration was 5 days. (G) Staff nurse presenting with widespread urticarial eruption involving her face, arms, torso, legs, and loins. Lesion onset was before presentation of COVID-19 clinical symptoms. (H) "Urticarial pattern with mild edema, perivascular inflammation, and dilated vessels in the upper dermis. Inset. vessels filled with neutrophils and mixed perivascular inflammation." Reproduced with permission from John Wiley and sons (A-F, H); BMJ Publishing Group Ltd. (G). The following original reports are credited Galván Casas et al..$^{11}$; Marzano et $a l^{50}$; van Damme et al. ${ }^{23}$; Najafzadeh et al. ${ }^{24}$; Cabrera-Hernández et al. ${ }^{25}$; Hassan. ${ }^{26}$ 
Table 2. Demographic and clinical details of urticarial rashes observed in COVID-19 patients

\begin{tabular}{|c|c|c|c|c|}
\hline $\begin{array}{l}\text { Article } \\
\text { and Year }\end{array}$ & $\begin{array}{c}\text { Number of Patients, } \\
\text { Age, Gender }\end{array}$ & $\begin{array}{c}\text { Suspected or } \\
\text { Confirmed COVID-19 }\end{array}$ & COVID-19 Cutaneous Manifestations & $\begin{array}{l}\text { Anatomical Location of } \\
\text { Cutaneous Manifestations }\end{array}$ \\
\hline $\begin{array}{l}\text { Askin } \\
\quad \text { et al. }(2020)^{16}\end{array}$ & $\begin{array}{l}\text { Total population: } 210 \text { patients } \\
\text { Male age, mean: } \\
57.44 \pm 17.259 \text { years } \\
\text { Female age, mean: } \\
58.80 \pm 15.918 \text { years } \\
123 \text { male }(58.6 \%), 87 \text { female }(41.4 \%) \\
\text { Skin lesions: } 52 / 210(24 \%) \text { : } \\
33 \text { male }(26.8 \%), 19 \text { female }(21.8 \%) \\
\text { Urticaria: } 7 / 52(13.5 \%)\end{array}$ & $\begin{array}{l}\text { SARS-CoV-2 PCR in total population, } \\
\text { PCR performed in } 158 \text { patients: } \\
\text { Positive: } 88 / 158(55.7 \%) \\
\text { Negative: } 70 / 158(44.3 \%) \\
\text { SARS-CoV-2 PCR in } 52 \text { patients } \\
\text { with cutaneous findings: } \\
\text { Positive: } 34 / 52(65.4 \%) \\
\text { Negative: } 18 / 52(34.6 \%)\end{array}$ & $\begin{array}{l}\text { Classification of skin lesions: } \\
\text { Erythematous scaly rash }(n=17,32.7 \%) \\
\text { Maculopapular rash }(n=12,23 \%) \\
\text { Urticarial lesions }(n=7,3.5 \%) \\
\text { Petechial purpuric rash }(n=4,7.7 \%) \\
\text { Necrosis }(n=4,7.7 \%) \\
\text { Enanthema, aphthous stomatitis }(n=3,5.8 \%) \\
\text { Vesicular rash }(n=3,5.8 \%) \\
\text { Pernio }(n=1,1.9 \%)\end{array}$ & $\begin{array}{l}\text { Urticarial lesions were } \\
\text { distributed across the } \\
\text { entire body }\end{array}$ \\
\hline $\begin{array}{l}\text { Bouaziz } \\
\qquad \text { et al. }(2020)^{44}\end{array}$ & $\begin{array}{l}\text { Total population: } 14 \text { patients } \\
\text { Age/gender NR } \\
\text { Skin lesions: } 14 / 14(100 \%) \\
\text { Urticaria: } 1 / 14(7.1 \%)\end{array}$ & $\begin{array}{l}\text { SARS-CoV-2 PCR in } 14 \text { patients: } \\
\text { Positive: } 14 / 14(100 \%)\end{array}$ & $\begin{array}{l}\text { Inflammatory lesions: } 7 / 14 \\
\text { Exanthema }(n=4) \\
\text { Chicken pox-like virus }(n=2) \\
\text { Cold urticaria }(n=1) \\
\text { Vascular lesions: } 7 / 14 \\
\text { Violaceous macules with "porcelain-like" } \\
\text { appearance }(n=1) \\
\text { Livedo ( } n=1) \\
\text { Non-necrotic purpura }(n=1) \\
\text { Necrotic purpura }(n=1) \\
\text { Chilblain appearance with Raynaud's } \\
\text { phenomenon }(n=1) \\
\text { Chilblain }(n=1) \\
\text { Eruptive cherry angioma }(n=1)\end{array}$ & $\mathrm{N} / \mathrm{A}$ \\
\hline $\begin{array}{l}\text { Dalal } \\
\qquad \text { et al. }(2020)^{27}\end{array}$ & $\begin{array}{l}\text { Total population: } 102 \text { patients } \\
\quad \text { Age, mean (SD): } 39.30 \text { years (SD 17.9) } \\
\quad 95 \text { male (93.1\%), } 7 \text { female }(6.9 \%) \\
\text { Skin lesions: } 13 / 102(12.7 \%) \\
\text { Urticaria: } 2 / 13(15.4 \%)\end{array}$ & $\begin{array}{l}\text { SARS-CoV-2 PCR in } 102 \text { patients: } \\
\text { Positive: 102/102 (100\%) }\end{array}$ & $\begin{array}{l}\text { Classification of skin lesions: } \\
\text { Maculopapular rash }(n=3,23.1 \%) \\
\text { Urticarial lesions ( } n=2,15.4 \%) \\
\text { Pruritis without specific cutaneous signs } \\
(n=8,69.2 \%)\end{array}$ & $\begin{array}{l}\text { Location of urticarial lesions: } \\
\text { Trunk }(n=2)\end{array}$ \\
\hline $\begin{array}{l}\text { De Giorgi } \\
\quad \text { et al. }(2020)^{17}\end{array}$ & $\begin{array}{l}\text { Total population: } 678 \text { patients } \\
\text { Skin lesions: } 53 / 678(7.8 \%) \\
\quad \text { Age, mean (range): } 55.9 \text { years (28-69) } \\
32 \text { male }(60 \%), 21 \text { female }(40 \%) \\
\text { Urticaria: } 14 / 53(26 \%)\end{array}$ & $\begin{array}{l}\text { SARS-CoV-2 PCR in } 678 \text { patients: } \\
\text { Positive: } 678 / 678(100 \%)\end{array}$ & $\begin{array}{l}\text { Inflammatory manifestations: } \\
\text { Erythematous rash }(n=37,70 \%) \\
\text { Diffuse urticaria }(n=14,26 \%) \\
\text { Varicelliform rash—vesiculation }(n=2,4 \%) \\
\text { Vascular manifestations: } \\
\text { Diffuse petechiae, purpura, } \\
\text { and acro-ischemia (25\%) }\end{array}$ & $\begin{array}{l}\text { Location of ALL lesions: } \\
\text { Trunk } \\
\text { Upper limbs }\end{array}$ \\
\hline $\begin{array}{l}\text { de Masson } \\
\text { et al. }(2020)^{15}\end{array}$ & $\begin{array}{l}\text { Total population: } 277 \text { patients } \\
\quad \text { Age, mean (range): } 27 \text { years (2-98) } \\
\text { "Half of patients were male" } \\
\text { Skin lesions: } 277 / 277(100 \%) \\
\text { Urticaria: } 26 / 277(9 \%) \\
\quad \text { Age, median (range): } 3 \text { years }(2-23) \\
13 \text { male }(56.5 \%), 10 \text { female }(43.5 \%)\end{array}$ & $\begin{array}{l}\text { SARS-CoV-2 PCR in } 34 \text { patients }(12 \%) \text { : } \\
\text { Positive: } 25 / 34(73.5 \%) \\
\text { Negative: } 9 / 34(26.5 \%)\end{array}$ & $\begin{array}{l}\text { Classification of skin lesions: } \\
\text { Morbilliform lesions }(n=25,9 \%) \\
\text { Acral lesions ( } n=142,51 \%) \\
\text { Vesicular lesions }(n=41,15 \%) \\
\text { Livedo reticularis }(n=4,1 \%) \\
\text { Urticarial lesions }(n=26,9 \%) \\
\text { Petechial lesions }(n=7,3 \%) \\
\text { Other types of lesions }(n=41,15 \%)\end{array}$ & $\begin{array}{l}\text { Location of urticarial lesions: } \\
\text { Trunk and limbs } \\
(n=24,92 \%) \\
\text { Face }(n=2,8 \%)\end{array}$ \\
\hline $\begin{array}{l}\text { Galvan } \\
\quad \text { et al. }(2020)^{11}\end{array}$ & $\begin{array}{l}\text { Total population: } 375 \text { patients } \\
153 \text { males }(40.8 \%) \text {, } \\
\quad 222 \text { females }(59.2 \%) \\
\text { Skin lesions: } 375 / 375(100 \%) \\
\text { Urticaria: } 73 / 375(19 \%) \text { : } \\
\quad \text { Age, mean }(S D)=48.7 \text { years }(19.9) \\
26 \text { male }(35.6 \%), 47 \text { female }(64.3 \%)\end{array}$ & $\begin{array}{l}\text { Laboratory confirmation of SARS-CoV-2 } \\
\text { Patients with skin lesions: } \\
\text { Confirmed: } 234 / 375(62.4 \%) \\
\text { Suspected: } 141 / 375(37.6 \%) \\
\text { Urticarial patients: } \\
\text { Confirmed: } 49 / 73(67 \%) \\
\text { Suspected: } 24 / 73(33 \%)\end{array}$ & $\begin{array}{l}\text { Classification: } \\
\text { Pseudo-chilblain (19\%) } \\
\text { Vesicular eruptions (9\%) } \\
\text { Urticarial lesions (19\%) } \\
\text { Maculopapular eruptions (47\%) } \\
\text { Livedo or necrosis }(6 \%)\end{array}$ & $\begin{array}{l}\text { Most urticarial lesions were } \\
\text { dispersed or located on the } \\
\text { trunk. A few cases were } \\
\text { located on the palms. }\end{array}$ \\
\hline $\begin{array}{l}\text { Recalcati } \\
\text { et al. }(2020)^{5}\end{array}$ & $\begin{array}{l}\text { Total population: } 88 \text { patients } \\
\quad \text { Age/gender-N/A } \\
\text { Skin lesions: } 18 / 88(20.5 \%) \\
\text { Urticaria: } 3 / 18(16.7 \%)\end{array}$ & $\begin{array}{l}\text { SARS-CoV-2 PCR: } \\
\text { Positive: } 18 / 18\end{array}$ & $\begin{array}{l}\text { Classification: } \\
\text { Erythematous rash }(n=14) \\
\text { Widespread urticaria }(n=3) \\
\text { Chicken pox-like vesicles }(n=1)\end{array}$ & $\begin{array}{l}\text { Trunk was the primary } \\
\text { location for all lesions. }\end{array}$ \\
\hline $\begin{array}{l}\text { Rubio-Muniz } \\
\text { et al. }(2020)^{14}\end{array}$ & $\begin{array}{l}\text { Total population: } 34 \text { patients } \\
\text { Age, median (range): } \\
54.5 \text { years ( } 31-66) \\
14 \text { male }(41 \%), 20 \text { female }(59 \%) \\
\text { Skin lesions: } 34 / 34(100 \%) \\
\text { Urticaria: } 4 / 34(11.8 \%) \\
\text { Age, median (range): } \\
54.5 \text { years (37-65) } \\
1 \text { male }(25 \%), 3 \text { female }(75 \%)\end{array}$ & $\begin{array}{l}\text { COVID-19 diagnosis (total population): } \\
\text { Positive PCR: } 17 / 34(50 \%) \\
\text { Positive radiology: } 8 / 24(23.5 \%) \\
\text { Negative PCR: } 9 / 34(26.5 \%) \\
\text { COVID-19 diagnosis (Urticarial): } \\
\text { Positive PCR: } 2 / 4(50 \%) \\
\text { Positive radiology: } 1 / 4(25 \%) \\
\text { Negative PCR: } 1 / 4(25 \%)\end{array}$ & $\begin{array}{l}\text { Classification: } \\
\text { Maculopapular }(n=10) \\
\text { Pseudo-chilblain }(n=9) \\
\text { Targetoid lesions }(n=5) \\
\text { Palpable purpura }(n=4 \text {, of which } 2 \text { cases } \\
\text { are with vesicular lesions) } \\
\text { Acute urticaria ( } n=3) \\
\text { Vesicular ( } n=2 \text {, these also } \\
\text { have palpable purpura) } \\
\text { Remaining } 3 \text { cases include livedo reticularis, } \\
\text { urticarial exanthem, and prurigo lesions. }\end{array}$ & $\mathrm{N} / \mathrm{A}$ \\
\hline $\begin{array}{l}\text { Gaspari } \\
\quad \text { et al. }(2020)^{42}\end{array}$ & $\begin{array}{l}\text { Total population: } 20 \text { patients } \\
\quad \text { Age, median: } 51 \text { years } \\
17 \text { male }(85 \%), 3 \text { female }(15 \%) \\
\text { Skin lesions: } 18 / 20(90 \%) \\
\text { Urticaria: } 2 / 18(11.1 \%)\end{array}$ & Confirmed: 18/18 (41\%) & $\begin{array}{l}\text { Classification: } \\
\text { Exanthematic rashes }(n=9) \\
\text { Acral vasculitis eruptions }(n=6) \\
\text { Polymorpho-like urticaria }(n=2) \\
\text { Varicellifom eruption }(n=1)\end{array}$ & $\begin{array}{l}\text { Figure 1: } \\
\text { Polymorpho-like urticaria } \\
\text { located on the left hand }\end{array}$ \\
\hline
\end{tabular}

NR, not reported. 
manifestations has varied from $7 \%$ to $40 \%$ in smaller case series. These lesions were common among middle-aged patients ${ }^{11,14}$; however, a retrospective study conducted in France reported a median age of 3 years of age among 26 patients with urticarial lesions. ${ }^{15}$ Many of these lesions were distributed on the trunk or limbs. ${ }^{11,15,27}$ In some cases, the rash was generalized across the entire body or localized to the face ${ }^{15,16}$ According to the largest case series of urticarial lesions, onset is thought to occur at the same time as other systemic symptoms of COVID-19 with an average duration of 6.8 days. ${ }^{11}$ However, it should be noted that in a few instances, the onset of urticaria has manifested before COVID-19's systemic symptoms. ${ }^{11,28}$

Galván Casas et al. reported pruritus in $92 \%$ of patients with urticarial lesions and associated these lesions with a more severe COVID-19 infection. ${ }^{11}$ Histopathological examination for urticarial lesions has been sparse; however, the results in one case of urticariform rash present in a 32-yearold woman displayed the presence of perivascular infiltrate of lymphocytes, with few eosinophils and upper dermal edema. ${ }^{29}$

Due to many cases of urticaria having an association with therapy, possible etiology of urticarial lesions could involve drug-induced exanthema. ${ }^{11}$ Urticaria has been described as a cutaneous side effect in many potential anti-COVID-19 drugs such as chloroquine, hydroxychloroquine, lopinavir/ ritonavir, nitazoxanide, corticosteroids, baricitinib, IVIG treatments, and checkpoint inhibitors. ${ }^{20}$ In addition to adverse drug effects, another possible pathophysiological mechanism leading to urticaria could be overactivity of the immune system, resulting in a potential "cytokine storm" involving the skin. ${ }^{30}$ Interestingly, cases of delayed pressure urticaria have also been reported, although they are thought to be a result of vertical pressure caused by PPE. ${ }^{31}$

Finally, a direct cutaneous effect by the SARS$\mathrm{CoV}-2$ virus is always a possibility, considering viral infections have sometimes been implicated as the primary agent in urticarial cases in the past. On account of the extreme variability in etiology of urticarial skin lesions, these lesions are thought to be a potentially inaccurate marker for diagnosis or verification of COVID. ${ }^{11}$ Other significant hypotheses about the potential causes of urticarial lesions have been provided in Table 9 .

\section{Chilblain-like lesions (COVID toes)}

Chilblain lesions, also referred to as pernio, are characterized as a localized inflammatory skin disorder, thought to be induced by exposure to cold temperatures or damp humid environments resulting in swelling and discoloration of the extremities (Fig. 4). The increased incidence of pernio/acral-like or chilblain-like lesions, coupled with the temporal association with viral symptoms, has led to the colloquialization "COVID toes." The term comes from the cutaneous description in which the skin involving their toes presents as erythematous or violaceous lesions. Although some cases are idiopathic, previous literature supports chilblain association with autoimmune diseases such as lupus. ${ }^{32}$ In some cases, the rash is seen with the Raynaud's phenomenon in which a trigger (cold exposure or emotional stress) leads to skin discolorations of extremities through vasoconstriction. ${ }^{33}$

A retrospective review conducted by Cappel et al. reported additional potential associations with hematologic disease as well as hyperviscosity syndrome. The rash is typically located on distal acral extremities such as fingers and/or toes. ${ }^{32}$ Per UpToDate, the rash typically presents as "erythematous-violaceous papules, macules, or nodules (UpToDate)." The pathogenesis behind chilblains is not entirely understood. One suspected mechanism revolves around cold-induced vasoconstriction and vasospasm leading to hypoxemia and inflammation. Other theories suggest hyperviscosity or autoantibody-induced endothelial damage (UpToDate). Treatment modalities include heating, nonsteroidal anti-inflammatory drugs (NSAIDs), topical steroids, and vasodilators. ${ }^{32}$

Lesions similar to chilblains, labeled as chilblain like or pernio like, have rapidly become the most familiar of COVID-19's cutaneous manifestations, in part, due to the numerous studies published concerning them (Table 3). The prevalence of these lesions varied considerably between studies. An international case series consisting of 505 patients with dermatological conditions reported pernio-like lesions present in 63\%. ${ }^{34}$ Among other studies, the prevalence of chilblain-like lesions fluctuated from $14.3 \%$ to $72 \%$. $^{11,15,34-36}$ These vascular lesions were commonly identified among adolescents and young adults. ${ }^{11,15,34,35,37-43}$ Anatomical locations of chilblain-like lesions were consistent between studies with feet and hands being affected the most often. On the hands and feet, the acral lesions would typically localize on the fingers and toes, respectively.

The onset of chilblain-like lesions was almost always after the onset of COVID-19's systemic symptoms and they normally lasted for about a week or two on average. In one case series, chilblain-like lesions were the only symptom in $55 \%$ of cases. ${ }^{34}$ Dermatological symptoms commonly associated with chilblain-like lesions were pain and pruritus. ${ }^{11,34,35,37,38}$ Many of the patients 


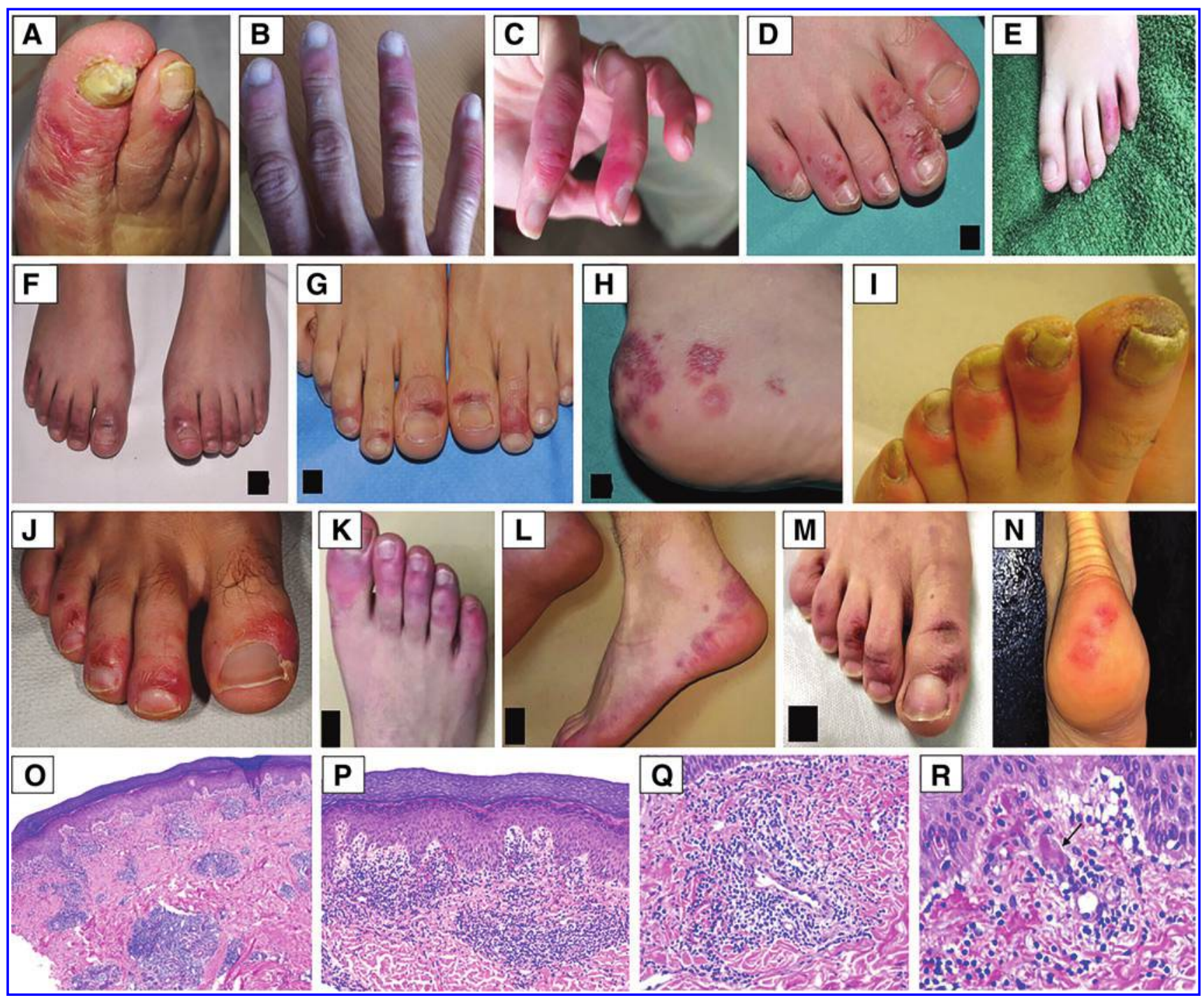

Figure 4. Examples of chilblain-like rash seen during the COVID-19 pandemic. (A) Acral chilblain-like lesions located on toes of patient. (B) Acral chilblainlike lesions located on fingers of patient. (C) Pseudo-chilblain lesions present on the fingers of pediatric patient with no prior history of chilblains. (D) Acral chilblain-like lesions located on toes of patient. (E) Chilblain-like lesions acrally located on toes of pediatric patient. (F, G) Lesions clinically similar to chilblains, acrally located on toes of child during COVID-19 pandemic. (H) Chilblain-like lesions located on the heel of an adolescent. (I) Chilblain-like acral lesion present on toes of patient from Italy. Examples of chilblain-like rash seen during the COVID-19 pandemic. (J) Acral pseudo-chilblains are seen on the toes of a patient. (K) Acral pernio-like lesions affecting the toes of patient. (L) Pernio-like lesions affecting the distal extremity of patient. (M) Acral chilblainlike lesions located on toes of an adolescent patient. (N) Pseudo-chilblain lesions described as erythemato-purpuric macules appeared on patient's heel. (O) "Dense, superficial, and deep angiocentric and eccrinotropic lymphocytic infiltrate (H\&E stain, 10×)." (P) "Papillary dermal edema, vacuolar degeneration of the basal layer and lymphocytic exocytosis. Endothelia of small vessels appear swollen (H\&E stain, 20×)." (Q) "Intense lymphocytic vascular reaction in dermal vessels (H\&E stain, 40×)." (R) "Red cell extravasation and focal thrombosis (arrow) in papillary dermis capillaries (H\&E stain, 100×)." H\&E, hematoxylin and eosin. Reproduced with permission from John Wiley and sons (A-R). The following original reports are credited: Galván Casas et al. ${ }^{11}$; Garcia-Lara et al. ${ }^{41}$; Andina et al. ${ }^{37}$; Wollina et al. ${ }^{43}$; Marzano et $a l^{50}$; Gaspari et al. ${ }^{42}$; Rubio-Muniz et al..$^{14}$

presenting with pernio-like lesions were young and healthy. These rashes were typically associated with relatively mild COVID-19 infections. ${ }^{34}$ Histopathological examination performed by RubioMuniz et al. showed different patterns. In many of the pseudo-chilblain cases, the histology displayed focal vacuolar degeneration of the basal layer. Regenerative changes were also observed in the epidermis along with perivascular lymphocytic cuffs in the dermal regions. Histology conducted in another sample discovered presence of perivascular neutrophilic cuffs with clear inflamed endothelium and regions of epidermal necrosis. ${ }^{14}$

The exact mechanism of chilblain-like lesions is not fully known as its presentation is unrelated to cold exposure. Bouaziz et al. hypothesized pathophysiology behind chilblain could involve "immune dysregulation, vasculitis, vessel thrombosis, or neoangiogensis. ${ }^{44}$ " It also noted previous cases with acro-ischemia and disseminated intravascu- 
Table 3. Demographic and clinical details of pseudo-chilblain rashes observed in COVID-19 patients

\begin{tabular}{|c|c|c|c|c|}
\hline $\begin{array}{l}\text { Article } \\
\text { and Year }\end{array}$ & $\begin{array}{c}\text { Number of Patients, } \\
\text { Age, Gender }\end{array}$ & $\begin{array}{c}\text { Suspected or } \\
\text { Confirmed COVID-19 }\end{array}$ & $\begin{array}{l}\text { COVID-19 Cutaneous } \\
\text { Manifestations }\end{array}$ & $\begin{array}{c}\text { Anatomical Location } \\
\text { of Cutaneous } \\
\text { Manifestations }\end{array}$ \\
\hline $\begin{array}{l}\text { Andina } \\
\quad \text { et al. }(2020)^{37}\end{array}$ & $\begin{array}{l}\text { Total population: } 22 \text { patients } \\
\text { Age, median (range): } \\
12 \text { years }(6-17) \\
13 \text { male }(59 \%), 9 \text { female }(41 \%) \\
\text { Skin lesions: } 22 / 22(100 \%) \\
\text { Chilblain like: } 22 / 22\end{array}$ & $\begin{array}{l}\text { SARS-CoV-2 PCR } \\
\text { in } 19 \text { patients }(86 \%) \text { : } \\
\text { Positive: } 1 / 19(5.3 \%) \\
\text { Negative: } 18 / 19(94.7 \%)\end{array}$ & $\begin{array}{l}\text { Acral chilbain-like lesions: } \\
\text { Concomitant erythema multiforme; } \\
\text { erythemato-violaceous or purpuric } \\
\text { macules; swollen toes with dusky } \\
\text { violaceous discoloration and less } \\
\text { frequently, dark ischemic areas } \\
\text { with superifical blisters }\end{array}$ & $\begin{array}{l}\text { Feet affected in all cases, } \\
\text { toes most common. } \\
(n=22) \\
\text { Lesions on fingers }(n=3)\end{array}$ \\
\hline $\begin{array}{l}\text { Bouaziz } \\
\text { et al. }(2020)^{44}\end{array}$ & $\begin{array}{l}\text { Total population: } 14 \text { patients } \\
\text { Age/gender NR } \\
\text { Skin lesions: } 14 / 14(100 \%) \\
\text { Chilblain like: } 2 / 14(14.3 \%)\end{array}$ & $\begin{array}{l}\text { SARS-CoV-2 PCR: } \\
\text { Positive: 14/14 (100\%) }\end{array}$ & $\begin{array}{l}\text { Inflammatory lesions }=7 / 14 \text { : } \\
\text { Exanthema }(n=4) \\
\text { Chicken pox-like virus }(n=2) \\
\text { Cold urticaria }(n=1) \\
\text { Vascular lesions }=7 / 14 \text { : } \\
\text { Violaceous macules with } \\
\text { "porcelain-like" appearance }(n=1) \\
\text { Livedo }(n=1) \\
\text { Non-necrotic purpura }(n=1) \\
\text { Necrotic purpura }(n=1) \\
\text { Chilblain appearance with Raynaud's } \\
\text { phenomenon }(n=1) \\
\text { Chilblain }(n=1) \\
\text { Eruptive cherry angioma }(n=1)\end{array}$ & $\mathrm{N} / \mathrm{A}$ \\
\hline $\begin{array}{l}\text { Colonna } \\
\text { et al. }(2020)^{38}\end{array}$ & $\begin{array}{l}\text { Total population: } 30 \text { patients } \\
\quad \text { Age, median (range) }= \\
\quad 11 \text { years }(2-17) \\
17 \text { male }(56.7 \%), 13 \text { female }(43.3 \%) \\
\text { Skin lesions: } 30 / 30(100 \%) \\
\text { Chilblain like: } 30 / 30\end{array}$ & $\begin{array}{l}\text { SARS-CoV-2 PCR } \\
\text { in } 6 \text { patients }(20 \%) \text { : } \\
\text { Negative: } 6 / 6\end{array}$ & $\begin{array}{l}\text { Chilblain-like acral lesions: } \\
\text { Lesions were erythematous-violaceous } \\
\text { patches or slightly infiltrated plaques. }\end{array}$ & $\begin{array}{l}\text { Location of lesions: } \\
\text { Feet ( } n=26) \\
\text { Ankles }(n=2) \\
\text { Hands ( } n=4) \\
\text { Of } 4 \text { patients with hand } \\
\text { lesions, } 2 \text { of them also } \\
\text { had foot lesions. }\end{array}$ \\
\hline $\begin{array}{l}\text { de Masson } \\
\quad \text { et al. }(2020)^{15}\end{array}$ & $\begin{array}{l}\text { Total population: } 277 \text { patients } \\
\text { Age, mean (range): } 27 \text { years (2-98) } \\
\text { "Half of patients were male" } \\
\text { Skin lesions: } 277 / 277(100 \%) \\
\text { Chilblain like: } 106 / 277(38 \%) \\
\text { Age, median (range): } \\
\quad 27 \text { years (6-73) }\end{array}$ & $\begin{array}{l}\text { SARS-CoV-2 PCR } \\
\text { in } 34 \text { patients }(12 \%) \text { : } \\
\text { Positive: } 25 / 34(73.5 \%) \\
\text { Negative: } 9 / 34(26.5 \%)\end{array}$ & $\begin{array}{l}\text { Classification: } \\
\text { Morbilliform lesions }(n=25,9 \%) \\
\text { Acral lesions }(n=142,51 \%) \\
\text { Vesicular lesions }(n=41,15 \%) \\
\text { Livedo reticularis }(n=4,1 \%) \\
\text { Urticarial lesions }(n=26,9 \%) \\
\text { Petechial lesions }(n=7,3 \%) \\
\text { Other types of lesions }(n=41,15 \%) \\
\text { Chilblain like: } 106 / 142 \text { acral lesions }\end{array}$ & $\begin{array}{l}\text { Location of } 34 \text { acral lesions: } \\
\text { Hands }(n=23,68 \%) \\
\text { Face }(n=18,53 \%)\end{array}$ \\
\hline $\begin{array}{l}\text { Duong } \\
\qquad \text { et al. }(2020)^{36}\end{array}$ & $\begin{array}{l}\text { Total population: } 295 \text { patients } \\
\quad \text { Age/gender NR } \\
\text { Skin lesions: } 295 / 295(100 \%) \\
\text { Chilblain like: } 146 / 295(49.5 \%)\end{array}$ & $\mathrm{N} / \mathrm{A}$ & $\begin{array}{l}\text { Classification: } \\
\text { Chilblain-like lesions ( } n=146) \text {, } \\
\text { Other manifestations such as urticaria, } \\
\text { rash, chicken pox like, or pityriasis } \\
\text { rosea }(n=149)\end{array}$ & $\mathrm{N} / \mathrm{A}$ \\
\hline $\begin{array}{l}\text { El Hachem } \\
\text { et al. }(2020)^{39}\end{array}$ & $\begin{array}{l}\text { Total population: } 19 \text { patients } \\
\text { Age, mean (range): } \\
\quad 14 \text { years (11-17) } \\
\text { Skin lesions: } 19 / 19(100 \%) \\
\text { Chilblain like: } 19 / 19\end{array}$ & $\begin{array}{l}\text { SARS-CoV-2 PCR: } \\
\text { Negative: 19/19 }\end{array}$ & $\begin{array}{l}\text { Acral chilblain-like lesions: } \\
\text { Swelling, erythema, purpuric macules } \\
\text { and papules, pustules, and crusts. }\end{array}$ & $\begin{array}{l}\text { Lesions almost exclusively } \\
\text { located on feet, } \\
\text { predominately distributed } \\
\text { to distal toes. In addition } \\
\text { to toes, } 9 \text { patients also } \\
\text { had lesions on soles and } \\
\text { heel. Minority of patients } \\
\text { had only hand lesions. }\end{array}$ \\
\hline
\end{tabular}


Table 3. (Continued)

\begin{tabular}{|c|c|c|c|c|}
\hline $\begin{array}{l}\text { Article } \\
\text { and Year }\end{array}$ & $\begin{array}{l}\text { Number of Patients, } \\
\text { Age, Gender }\end{array}$ & $\begin{array}{c}\text { Suspected or } \\
\text { Confirmed COVID-19 }\end{array}$ & $\begin{array}{l}\text { COVID-19 Cutaneous } \\
\text { Manifestations }\end{array}$ & $\begin{array}{c}\text { Anatomical Location } \\
\text { of Cutaneous } \\
\text { Manifestations }\end{array}$ \\
\hline $\begin{array}{l}\text { Freeman } \\
\qquad \text { et al. }(2020)^{34}\end{array}$ & $\begin{array}{l}\text { Total population: } 505 \text { patients } \\
\text { Skin lesions: 505/505 (100\%) } \\
\text { Chilblain like: } 318 / 505(63 \%) \\
\text { Age, mean (IQR): } 25 \text { years (17-38) } \\
163 \text { male }(51 \%), 155 \text { female }(49 \%)\end{array}$ & $\begin{array}{l}\text { Confirmed: } 23 / 318 \text { (7.23\%) } \\
\text { Suspected: } 295 / 318 \text { (92.8\%) }\end{array}$ & $\begin{array}{l}\text { Acral chilblain-like lesions: } \\
\text { Acrocyanosis in } 9.2 \% \\
\text { Acral desquamation in } 4.4 \%\end{array}$ & $\begin{array}{l}\text { Location of lesions: } \\
\text { Only on feet }(84 \%) \\
\text { Only on hands }(5.1 \%) \\
\text { Combination of hands } \\
\text { and feet }(10 \%)\end{array}$ \\
\hline $\begin{array}{l}\text { Garcia-Lara } \\
\quad \text { et al. }(2020)^{41}\end{array}$ & $\begin{array}{l}\text { Total population: } 27 \text { patients } \\
\quad \text { Age, mean: } 14.4 \text { years } \\
18 \text { male }(66 \%), 9 \text { female }(34 \%) \\
\text { Skin lesions: } 27 / 27(100 \%) \\
\text { Chilblain like: } 25 / 27(92.6 \%)\end{array}$ & $\begin{array}{l}\text { SARS-CoV- } 2 \text { tests: } \\
\text { PCR negative }(n=2) \\
\text { IgM negative }(n=9) \\
\text { IgA negative }(n=9) \\
\text { IgG negative }(n=9)\end{array}$ & $\begin{array}{l}\text { Classification: } \\
\text { Chilblain-like lesions ( } n=25,92.6 \%) \\
\text { Erythema multiforme-like rash } \\
\quad(n=2,7.4 \%)\end{array}$ & $\begin{array}{l}\text { Location of lesions: } \\
\text { Only on feet }(74 \%) \\
\text { Only on hands }(22 \%) \\
\text { Combination of hands } \\
\text { and feet }(4 \%)\end{array}$ \\
\hline $\begin{array}{l}\text { Rubio-Muniz } \\
\text { et al. }(2020)^{14}\end{array}$ & $\begin{array}{l}\text { Total population: } 34 \text { patients } \\
\text { Age, median (range): } 54.5 \\
\text { years (31-66) } \\
14 \text { male }(41 \%), 20 \text { female }(59 \%) \\
\text { Skin lesions: } 34 / 34(100 \%) \\
\text { Chilblain like: } 9 / 34(26.5 \%)\end{array}$ & $\begin{array}{l}\text { COVID-19 diagnosis (total population): } \\
\text { Positive PCR: } 17 / 34(50 \%) \\
\text { Positive radiology: } 8 / 24(23.5 \%) \\
\text { Negative PCR: } 9 / 34(26.5 \%) \\
\text { COVID-19 diagnosis (pseudo-chilblain: } \\
9 \text { cases with livedo: } 1 \text { case): } \\
\text { Positive PCR: } 2 / 10(20 \%) \\
\text { Positive radiology: } 2 / 10(20 \%) \\
\text { Negative PCR: } 6 / 10(60 \%)\end{array}$ & $\begin{array}{l}\text { Classification: } \\
\text { Maculopapular }(n=10) \\
\text { Pseudo-chilblain }(n=9) \\
\text { Targetoid lesions }(n=5) \\
\text { Palpable purpura ( } n=4 \text {, of which } 2 \text { cases } \\
\text { are with vesicular lesions) } \\
\text { Acute urticaria }(n=3) \\
\text { Vesicular ( } n=2 \text {, these also have } \\
\text { palpable purpura) } \\
\text { Remaining } 3 \text { cases include livedo } \\
\text { reticularis, urticarial exanthem, } \\
\text { and prurigo lesions. }\end{array}$ & N/A \\
\hline
\end{tabular}

$\lg A$, immunoglobulin $A$; IgG, immunoglobulin $G$; IgM, immunoglobulin $M$; IOR, interquartile range.

lar coagulation (DIC) from initial reports from Wuhan, China. The three main hypotheses of the article were confounding factors, postviral immune response, or immune antiviral response. ${ }^{44}$ In regard to a hypercoagulable state, one of the studies reported the presence of microthrombi. ${ }^{39}$ Recent studies have not been able to associate chilblainlike lesions with positive COVID-19 infections; therefore; these lesions should not be considered an accurate indicator for diagnosis of COVID-19. ${ }^{45,46}$ 
Other significant hypotheses about the potential causes of chilblain-like lesions have been provided in Table 9.

\section{Vesicular lesions}

Vesicular is a descriptive term used to characterize lesions that are clear fluid-filled sacs under the epidermal layer. These lesions are commonly referred to as blisters and tend to be less than $1 \mathrm{~cm}$ in diameter, with many often appearing in clusters. Most common causes are heat, contact dermatitis, medications, autoimmune, or infectious (bacterial or viral). Examples of viral infections that display vesicular lesions include varicella-zoster, herpes simplex, coxsackievirus, and echovirus infections. ${ }^{47}$

The prevalence of vesicular lesions among COVID-19 patients with cutaneous manifestations is not very common when compared to the lesions mentioned earlier (Fig. 5). Various studies have reported percentages ranging from $3.77 \%$ to $15 \%$. Vesicular lesions typically appear in middle-aged patients $^{11,15,48-50}$ (Table 4). The trunk of the body was the most common location for this type of rash; however, a fair number of these lesions were also identified on the extremities. ${ }^{11,15,16,48-50} \mathrm{~A}$ prospective study conducted by Fernandez-Nieto et al. was able to further characterize vesicular rash. Among 22 patients with vesicular lesions, $75 \%$ of them presented with a diffuse pattern of polymorphic lesions and $25 \%$ displayed a localized pattern of monomorphic lesions on the trunk. ${ }^{48}$ Other cases have also identified monomorphic vesicles located on the trunk. ${ }^{11,16}$ The time of onset of cutaneous manifestations relative to other COVID-19 symptoms varied between the few studies reported.

A study from Spain found the majority of vesicular lesions to occur at the same time as other systemic symptoms, ${ }^{11}$ while two studies from Italy reported most of their lesions appearing after COVID-19 symptoms. ${ }^{48-50}$ The studies with later onset of cutaneous manifestations had median latency times of 3 days and 14 days. ${ }^{48-50}$ Despite differences in rash onset, the studies did report a few cases of vesicular lesions appearing before COVID19 symptoms. Duration of rash in the Spanish study was 8.4 days on average. ${ }^{11}$ The two Italian studies reported median duration of rash being 8 and 10 days. $^{48,49}$ Prevalence of additional pruritic symptoms among patients with vesicular lesions fluctuated between $40.9 \%$ and $83.3 \%$ depending on which study. ${ }^{11,48-50}$ Vesicular lesions are thought to be associated with intermediate severity of COVID19. ${ }^{11,48}$ Histopathological examination was performed in two studies and both described their findings as being consistent with known viral infections. ${ }^{48,49}$ In the first study, the skin biopsies of two cases revealed presence of intraepidermal vesicles associated with mild acantolisis and ballooned keratinocytes. ${ }^{48}$ Second study conducted skin biopsies in seven patients with histological examination showing "basket-wave hyperkeratosis; slightly atrophic epidermis; and vacuolar degeneration of the basal layer with multinucleate, hyperchromatic keratinocytes and dyskeratotic cells." ${ }^{49}$

There are a few theories regarding the pathophysiologic mechanisms involved with vesicular lesions. Criado et al. mentioned that vesicular eruption could be a result of immune system overactivity causing a potential "cytokine storm" involving the skin. ${ }^{30}$ The same study hypothesized a direct cytopathic effect of SARS-CoV-2 on endothelium dermal vessels could produce vesicular lesions. ${ }^{30}$ Unlike maculopapular and urticarial lesions, vesicular lesions associated with COVID-19 are thought to be etiologically unrelated to antiviral drugs or other COVID-19 treatments. ${ }^{48}$ Finally, vesicular lesions have been described as "specific cutaneous manifestations" of COVID-19; therefore, their identification could potentially be useful for diagnosis. Other significant hypotheses about the potential causes of vesicular lesions have been provided in Table 9.

\section{Petechiae/purpura lesions}

Petechiae are typically described as being small nonblanching spots that are less than $2 \mathrm{~mm}$ in diameter. $^{51,52}$ These miniature lesions are characterized as nonblanching due to them not vanishing after brief pressure is applied to the skin manifestation area. If the nonblanching lesions are greater than $2 \mathrm{~mm}$ in diameter, they are labeled as purpura. These subdermal hemorrhages have many pathophysiological causes, including "thrombocytopenia, platelet dysfunction, disorders of coagulation, and loss of vascular integrity. ${ }^{51 "}$ Petechial rashes are associated with some viral infections, including enterovirus, parvovirus B19, and dengue virus. $^{51}$

Petechiae/purpura rashes are among the less commonly described cutaneous manifestations in association with COVID-19 (Fig. 6). A retrospective study from France consisting of 277 patients with skin lesions reported petechial patterns present in only $3 \%$ of patients (Table 5). The lesions were located diffusely, acral, or on limbs. ${ }^{15}$ Another study involving petechial purpuric rash noticed that the majority of cases were petechiae located on distal extremities. ${ }^{16}$ Two case series with a small number of petechiae/purpuric lesions reported their onset 


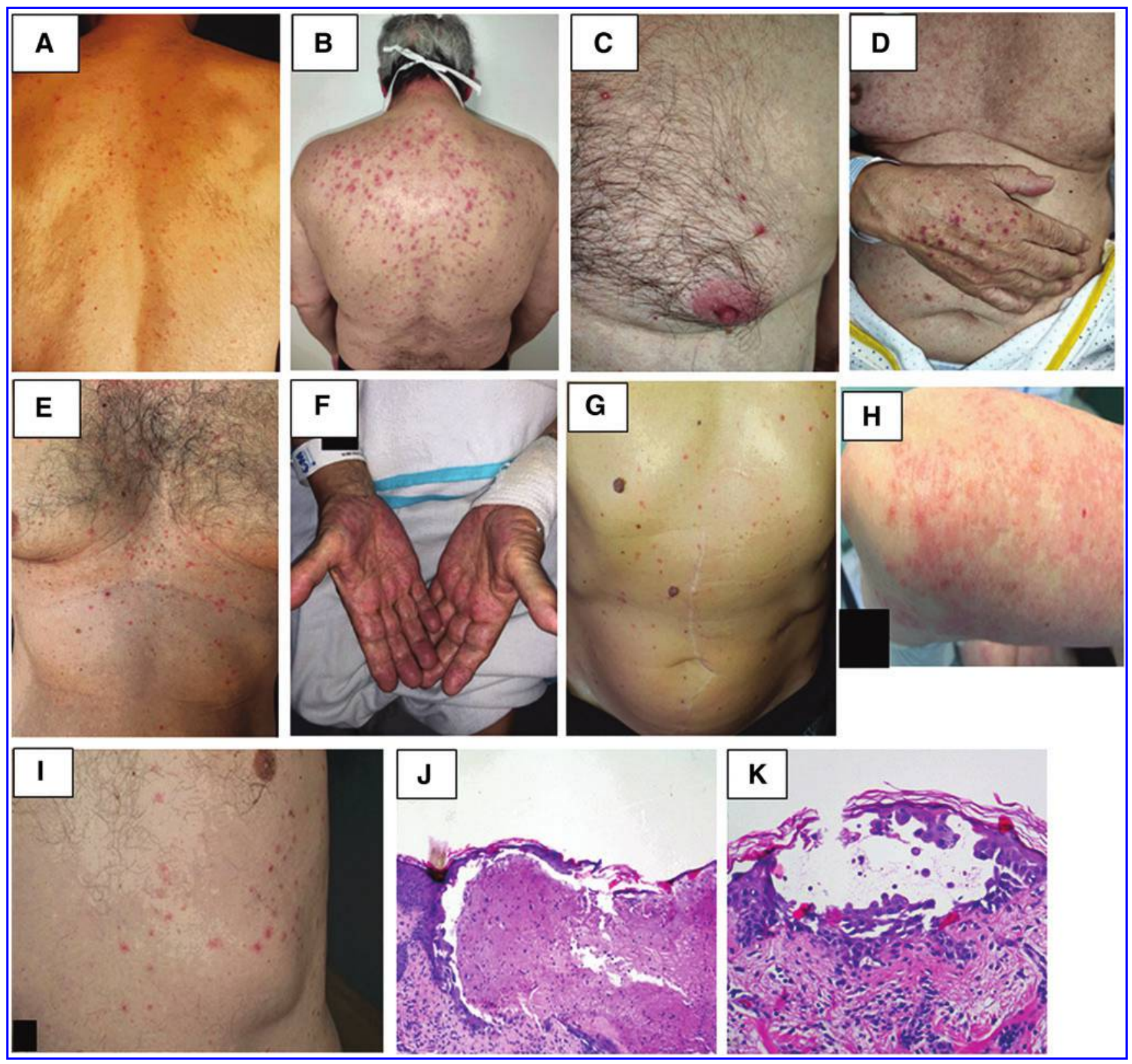

Figure 5. Examples of vesicular rash seen during the COVID-19 pandemic. (A) Vesicular lesions, characterized as monomorphic, dispersed along patient's back. (B) Polymorphic vesicular lesions diffusely affecting patient's entire trunk and upper/lower extremities. (C) Vesicular lesions scattered or clustered along patient's trunk. (D) Maculopapular lesions disseminated along patient's trunk with additional vesicular lesions located on distal upper extremities (hands). (E) Vesicular rash localized to patient's anterior trunk with lesions appearing as monomorphic. (F) Patient's palmar surfaces exhibiting vesicles. (G) Dispersed vesicular rash appearing on the anterior trunk of a patient. (H) Patient presented with atypical papulovesicular eruptions, in addition to the purpuric lesions. (I) Vesicular rash, similar in appearance to chicken pox, located along patient's anterior trunk. (J) "Histological examination showing an intraepidermal vesicle containing scattered multinucleated and ballooned keratinocytes, with mild acantolisis." (K) "A deeper section of the vesicle reveals more extensive damage, with epidermal detachment and confluent keratinocytic necrosis. The vesicle contains fibrinoid material with acute inflammation." Reproduced with permission from John Wiley and sons (A-H, J-K); Wolters Kluwer Health, Inc. (I). The following original reports are credited: Galván Casas et al. ${ }^{11}$; Fernandez-Nieto et al. ${ }^{48}$; Marzano et al. ${ }^{50}$; Rubio-Muniz et al..$^{14}$; Gianotti et al. ${ }^{18}$

to be after COVID-19 symptoms. ${ }^{14,53}$ De Giorgi et al. stated that diffuse petechiae and generalized palpable purpura usually appeared in cases with a greater severity of infection. ${ }^{17}$ This statement was supported through a case series conducted in Spain claiming that palpable purpuric lesions, present in 4 of 34 cases (11.8\%), were more frequent in middle- aged patients recovering from severe COVID-19 infections. Interestingly, of the four patients presenting with palpable purpuric lesions, two of them additionally exhibited atypical polymorphic papulovesicular eruptions, while a third patient also displayed an urticarial exanthem. ${ }^{14}$ A rare case of necrotic purpura was reported among 2 purpura 
Table 4. Demographic and clinical details of vesicular lesions observed in COVID-19 patients

\begin{tabular}{|c|c|c|c|c|}
\hline $\begin{array}{l}\text { Article } \\
\text { and Year }\end{array}$ & $\begin{array}{c}\text { Number of Patients, } \\
\text { Age, Gender }\end{array}$ & $\begin{array}{c}\text { Suspected } \\
\text { or Confirmed COVID-19 }\end{array}$ & COVID-19 Cutaneous Manifestations & $\begin{array}{c}\text { Anatomical Location of } \\
\text { Cutaneous } \\
\text { Manifestations }\end{array}$ \\
\hline $\begin{array}{l}\text { Askin } \\
\text { et al. }(2020)^{16}\end{array}$ & $\begin{array}{l}\text { Total population: } 210 \text { patients } \\
\text { Male age, mean: } \\
57.44 \pm 17.259 \text { years } \\
\text { Female age, mean: } \\
58.80 \pm 15.918 \text { years } \\
123 \text { male }(58.6 \%) \text {, } \\
87 \text { female }(41.4 \%) \\
\text { Skin lesions: } 52 / 210(24 \%) \text { : } \\
33 \text { male }(26.8 \%) \text {, } \\
19 \text { female }(21.8 \%) \\
\text { Vesicular: } 3 / 52(5.8 \%)\end{array}$ & $\begin{array}{l}\text { SARS-CoV-2 PCR in total population, } \\
\text { PCR performed in } 158 \text { patients: } \\
\text { Positive: } 88 / 158(55.7 \%) \\
\text { Negative: } 70 / 158(44.3 \%) \\
\text { SARS-CoV-2 PCR in } 52 \text { patients } \\
\text { with cutaneous findings: } \\
\text { Positive: } 34 / 52(65.4 \%) \\
\text { Negative: } 18 / 52(34.6 \%)\end{array}$ & $\begin{array}{l}\text { Classification of } 52 \text { patients with skin lesions: } \\
\text { Erythematous scaly rash }(n=17,32.7 \%) \\
\text { Maculopapular rash }(n=12,23 \%) \\
\text { Urticarial lesions }(n=7,3.5 \%) \\
\text { Petechial purpuric rash }(n=4,7.7 \%) \\
\text { Necrosis }(n=4,7.7 \%) \\
\text { Enanthema, aphthous stomatitis }(n=3,5.8 \%) \\
\text { Vesicular rash }(n=3,5.8 \%) \\
\text { Pernio }(n=1,1.9 \%)\end{array}$ & $\begin{array}{l}\text { Location of vesicular lesions: } \\
\text { A couple of them were } \\
\text { "unilateral and monomorphic } \\
\text { on the upper part of } \\
\text { the trunk" }\end{array}$ \\
\hline $\begin{array}{l}\text { Bouaziz } \\
\text { et al. }(2020)^{44}\end{array}$ & $\begin{array}{l}\text { Total population: } 14 \text { patients } \\
\quad \text { Age/gender NR } \\
\text { Skin lesions: } 14 / 14(100 \%) \\
\text { Vesicular: } 2 / 14(14.3 \%)\end{array}$ & $\begin{array}{l}\text { SARS-CoV-2 PCR in } 14 \text { patients: } \\
\text { Positive: } 14 / 14(100 \%)\end{array}$ & $\begin{array}{l}\text { Inflammatory lesions: } 7 / 14 \\
\text { Exanthema }(n=4) \\
\text { Chicken pox-like virus ( } n=2) \\
\text { Cold urticaria }(n=1) \\
\text { Vascular lesions: } 7 / 14 \\
\text { Violaceous macules with "porcelain-like" } \\
\text { appearance }(n=1) \\
\text { Livedo }(n=1) \\
\text { Non-necrotic purpura }(n=1) \\
\text { Necrotic purpura }(n=1) \\
\text { Chilblain appearance with Raynaud's } \\
\text { phenomenon }(n=1) \\
\text { Chilblain }(n=1) \\
\text { Eruptive cherry angioma }(n=1)\end{array}$ & $\mathrm{N} / \mathrm{A}$ \\
\hline $\begin{array}{l}\text { De Giorgi } \\
\text { et al. }(2020)^{17}\end{array}$ & $\begin{array}{l}\text { Total population: } 678 \text { patients } \\
\text { Skin lesions: } 53 / 678(7.8 \%) \\
\text { Age, mean (range): } \\
55.9 \text { years (28-69) } \\
32 \text { male }(60 \%), 21 \text { female }(40 \%) \\
\text { Vesicular: } 2 / 53(4 \%)\end{array}$ & $\begin{array}{l}\text { SARS-CoV-2 PCR in } 678 \text { patients: } \\
\text { Positive: } 678 / 678(100 \%)\end{array}$ & $\begin{array}{l}\text { Inflammatory manifestations: } \\
\text { Erythematous rash }(n=37,70 \%) \\
\text { Diffuse urticaria }(n=14,26 \%) \text { Varicelliform } \\
\text { rash-vesiculation }(n=2,4 \%) \\
\text { Vascular manifestations: } \\
\text { Diffuse petechiae, purpura, } \\
\text { and acro-ischemia }(25 \%)\end{array}$ & $\begin{array}{l}\text { Location of ALL lesions: } \\
\text { Trunk } \\
\text { Upper limbs }\end{array}$ \\
\hline $\begin{array}{l}\text { Fernandez-Nieto } \\
\text { et al. }(2020)^{48}\end{array}$ & $\begin{array}{l}\text { Total population: } 24 \text { patients: } \\
\text { Skin lesions: } 24 / 22 \\
\text { Vesicular: } 24 / 24 \\
\text { Age, mean (range): } \\
45 \text { years }(19-65) \\
6 \text { male }(25 \%), 18 \text { female }(75 \%)\end{array}$ & $\begin{array}{l}\text { SARS-CoV-2 PCR: } \\
\text { Positive: } 24 / 24 \text { (100\%) } \\
\text { (Positive nasopharyngeal swab) }\end{array}$ & $\begin{array}{l}\text { Classification: } \\
\text { Disseminated pattern in } 18 \text { pts }(75 \%) \text { - } \\
\text { Diffuse described as small papules, } \\
\text { vesicles, pustules with varying sizes } \\
\text { (7-8 mm in diameter), also } \\
\text { lesions appeared in different stages. } \\
\text { Localized pattern in } 6 \text { patients ( } 25 \%)- \\
\text { Localized pattern was monomorphic, } \\
3-4 \mathrm{~mm} \text { diameter, same stage } \\
\text { of evolution }\end{array}$ & $\begin{array}{l}\text { Location of vesicular lesions: } \\
\text { Head }(n=4,22.2 \%) \\
\text { Anterior trunk }(n=17,94.4 \%) \\
\text { Posterior trunk }(n=12,66.7 \%) \\
\text { Arms }(n=8,44.4 \%) \\
\text { Legs }(n=10,55.6 \%) \\
\text { Palms/soles }(n=2,11.1 \%)\end{array}$ \\
\hline $\begin{array}{l}\text { Galvan } \\
\quad \text { et al. }(2020)^{11}\end{array}$ & $\begin{array}{l}\text { Total population: } 375 \text { patients } \\
153 \text { males }(40.8 \%) \text {, } \\
\quad 222 \text { females }(59.2 \%) \\
\text { Skin lesions: } 375 / 375(100 \%) \\
\text { Vesicular: } 34 / 375(9 \%) \\
\quad \text { Age, mean }(S D)=45.6 \text { years }(20) \\
\quad 15 \text { male }(44 \%), 19 \text { female }(56 \%)\end{array}$ & $\begin{array}{l}\text { Laboratory confirmation } \\
\text { of SARS-CoV-2 } \\
\text { Patients with skin lesions: } \\
\text { Confirmed: } 234 / 375(62.4 \%) \\
\text { Suspected: } 141 / 375(37.6 \%) \\
\text { Vesicular patients: } \\
\text { Confirmed: } 17 / 34(50 \%) \\
\text { Suspected: } 17 / 34(50 \%)\end{array}$ & $\begin{array}{l}\text { Classification: } \\
\text { Pseudo-chilblain (19\%) } \\
\text { Vesicular eruptions }(9 \%) \\
\text { Urticarial lesions (19\%) } \\
\text { Maculopapular eruptions (47\%) } \\
\text { Livedo or necrosis }(6 \%)\end{array}$ & $\begin{array}{l}\text { Location of vesicular lesions: } \\
\text { Trunk and limbs. }\end{array}$ \\
\hline $\begin{array}{l}\text { Marzano } \\
\text { et al. }(2020)^{49}\end{array}$ & $\begin{array}{l}\text { Total population: } 22 \text { patients } \\
\text { Age, median: } 60 \text { years } \\
16 \text { male }(72.7 \%) \text { and } \\
6 \text { female }(27.3) \\
\text { Skin lesions }=22 / 22(100 \%)\end{array}$ & $\begin{array}{l}\text { SARS-CoV-2 PCR: } \\
\text { Positive: } 12 / 22 \\
\text { Negative: } 7 / 22 \\
\text { Not tested: } 3 / 22\end{array}$ & $\begin{array}{l}\text { Classification: } \\
\text { Varicella-like exanthem, papulovesicular } \\
\text { pattern with predominance of papules } \\
\text { or vesicles in individual patients }\end{array}$ & $\begin{array}{l}\text { Vesicular lesions: } \\
\text { Scattered }(n=16) \\
\text { Diffuse }(n=6) \\
\text { Truncal involvement }(n=22) \\
\text { Limbs }(n=4)\end{array}$ \\
\hline
\end{tabular}




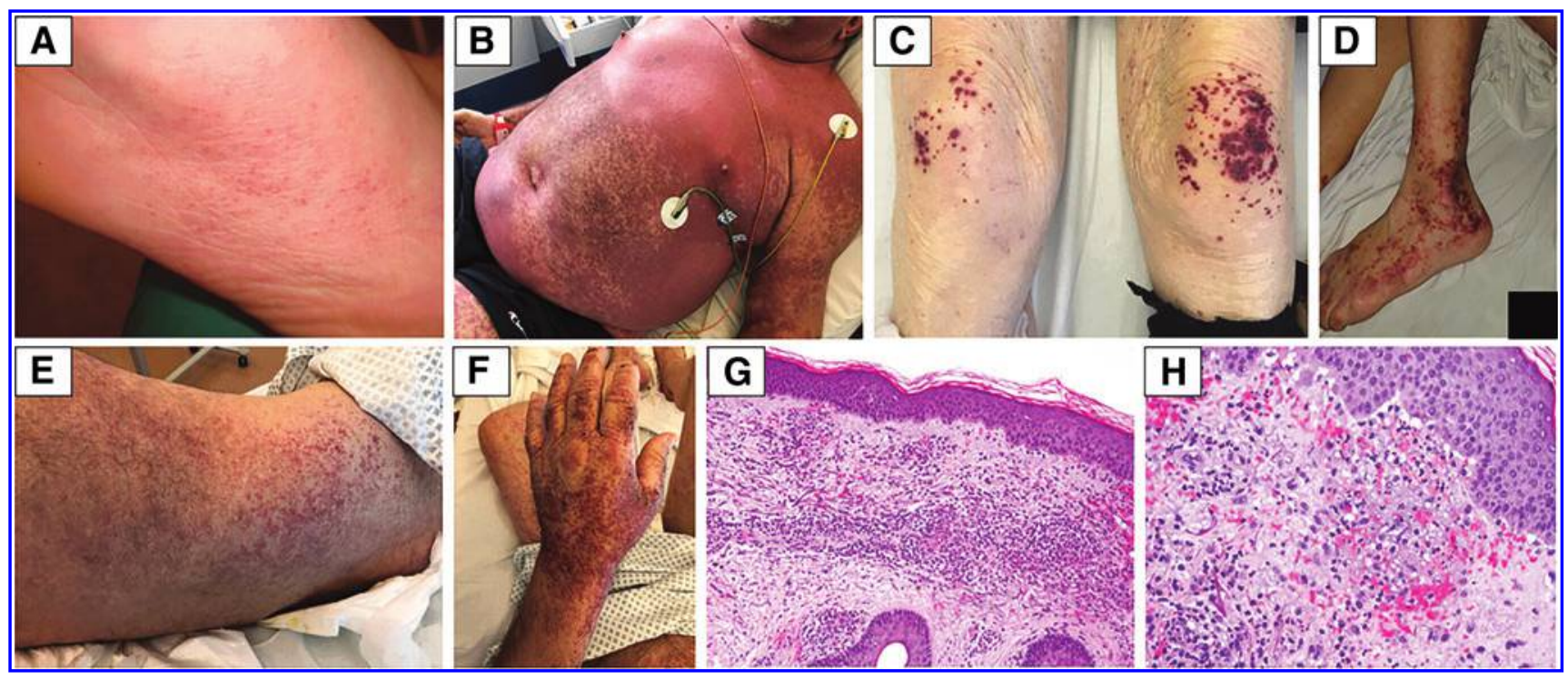

Figure 6. Examples of petechial/purpuric rash seen during the COVID-19 pandemic. (A) Purpuric rash thought to be associated with mild COVID-19 infections according to Wollina et al. (B) Rash on patient's chest is described as erythematous. Additional petechial lesions are exhibited on patient's abdomen and arms. (C) Purpuric lesions present on knees of patient. (D) Palpable purpuric lesions, resulting from subdermal hemorrhages, were distally located on lower extremity of COVID-19 hospitalized patient. (E) Maculopapular purpuric exanthema presenting symmetrically on the trunk of a 59-year-old man with severe respiratory failure due to COVID-19. (F) Purpuric eruption on the distal upper extremities of a 59-year-old man with severe COVID-19 infection. (G, H) "Skin biopsy revealed a dermal perivascular neutrophilic infiltrate $(H \& E, 10 \times)$ with sparse leukocytoclasis, red blood cell extravasation, and fibrinoid necrosis $(H \& E$, $40 \times$ )." Reproduced with permission from John Wiley and sons (A, H). The following original reports are credited: Wollina et al. ${ }^{43}$; Marzano et al.50; Rubio-Muniz et al. ${ }^{14}$; Caputo et al..$^{52}$

cases seen in 14 positive COVID-19 patients with cutaneous manifestations. ${ }^{44}$ Finally, a case series of five patients suffering from respiratory failure due to severe COVID-19 infections had three of the patients exhibiting purpuric skin rashes. ${ }^{53}$ Histopathological examination involving one of these patients with retiform purpura showed significant interstitial and perivascular neutrophilia along with prominent leukocytoclasia. ${ }^{53}$

Proposed pathogenesis for petechiae/purpura skin lesions involves a "pauci-inflammatory thrombogenic vasculopathy." Immunohistochemistry performed by Magro et al. displayed extensive deposition of complement components C5b-9 and $\mathrm{C} 4 \mathrm{~d}$ within the cutaneous microvasculature of both lesional and nonlesional (normal appearing) skin. These complement components could sometimes be seen colocalized with COVID-19 spike glycoproteins. ${ }^{53}$ Due to the severity of COVID-19 cases seen with petechiae/purpura an alternate etiology of the lesions could involve adverse dermatological effects associated with potential COVID-19 drugs. Cutaneous side effects of highdose IVIG treatments include petechiae among many others. Purpura is an adverse skin effect of the possible anti-COVID-19 agent camostat mesylate ${ }^{20}$ Finally, a direct cutaneous manifestation from SARS-CoV-2 could be a possibility considering petechiae are the result of other viral infec- tions. Other significant hypotheses about the potential causes of petechiae/purpura lesions have been provided in Table 9 .

\section{Livedoid eruption lesions}

Livedo reticularis (LR) is a transient or persistent cutaneous manifestation that classically presents with a reticular (net-like, lace-like) pattern of reddish-blue to purple mottled discolorations (Fig. 7). This dermatosis is a consequence of disturbed cutaneous vasculature yielding diminished blood flow and deoxygenated hemoglobin to the skin. Benign manifestations of livedoid eruptions that primarily occur due to physiological conditions (cutus marmorata) or idiopathically are referred to as being LR. Livedoid eruptions that occur secondary to pathological conditions are termed livedo racemosa (LRC) ${ }^{54}$ LRC presents as a permanent manifestation while exhibiting a more widespread appearance on the body and a broken/irregular shape compared to LR. ${ }^{54}$

Livedoid eruptions appear to be one of the least common cutaneous manifestations reported during the COVID-19 pandemic (Table 6). In a study of 375 confirmed COVID-19 patients with cutaneous manifestations, only $6 \%$ of them presented with varying degrees of livedoid lesions and necrosis. ${ }^{11}$ Anatomical locations for these lesions include the 
Table 5. Demographic and clinical details of petechiae/purpura lesions observed in COVID-19 patients

\begin{tabular}{|c|c|c|c|c|}
\hline $\begin{array}{l}\text { Article } \\
\text { and Year }\end{array}$ & $\begin{array}{c}\text { Number of Patients, } \\
\text { Age, Gender }\end{array}$ & $\begin{array}{c}\text { Suspected or } \\
\text { Confirmed COVID-19 }\end{array}$ & $\begin{array}{l}\text { COVID-19 Cutaneous } \\
\text { Manifestations }\end{array}$ & $\begin{array}{c}\text { Anatomical Location } \\
\text { of Cutaneous } \\
\text { Manifestations }\end{array}$ \\
\hline $\begin{array}{l}\text { Askin } \\
\quad \text { et al. }(2020)^{16}\end{array}$ & $\begin{array}{l}\text { Total population: } 210 \text { patients } \\
\text { Male age, mean: } \\
57.44 \text { years (17.259) } \\
\text { Female age, mean: } \\
58.80 \text { years }(15.918) \\
123 \text { male }(58.6 \%), 87 \text { female }(41.4 \%) \\
\text { Skin lesions: } 52 / 210(24 \%) \\
33 \text { male (26.8\%), } 19 \text { female }(21.8 \%) \\
\text { Petechiae/Purpura: } 4 / 52(7.7 \%)\end{array}$ & $\begin{array}{l}\text { SARS-CoV-2 PCR in total population, } \\
\text { PCR performed in } 158 \text { patients: } \\
\text { Positive: } 88 / 158(55.7 \%) \\
\text { Negative: } 70 / 158(44.3 \%) \\
\text { SARS-CoV-2 PCR in } 52 \text { patients } \\
\text { with cutaneous findings: } \\
\text { Positive: } 34 / 52(65.4 \%) \\
\text { Negative: } 18 / 52(34.6 \%)\end{array}$ & $\begin{array}{l}\text { Classification from } 52 \text { patients } \\
\text { with skin lesions: } \\
\text { Erythematous scaly rash } \\
(n=17,32.7 \%) \\
\text { Maculopapular rash }(n=12,23 \%) \\
\text { Urticarial lesions }(n=7,3.5 \%) \\
\text { Petechial purpuric rash }(n=4,7.7 \%) \\
\text { Necrosis ( } n=4,7.7 \%) \\
\text { Enanthema, aphthous stomatitis } \\
(n=3,5.8 \%) \\
\text { Vesicular rash }(n=3,5.8 \%) \\
\text { Pernio }(n=1,1.9 \%)\end{array}$ & $\begin{array}{l}\text { Location of petechial lesions: } \\
\text { Petechiae located on distal } \\
\text { extremities }(n=3) \\
\text { Generalized petechial purpuric } \\
\text { eruption }(n=1)\end{array}$ \\
\hline $\begin{array}{l}\text { Bouaziz } \\
\text { et al. }(2020)^{44}\end{array}$ & $\begin{array}{l}\text { Total population: } 14 \text { patients } \\
\text { Age/gender N/A } \\
\text { Skin lesions: } 14 / 14(100 \%) \\
\text { Purpura: } 2 / 14 \text { (14.3\%) } \\
\text { Non-necrotic purpura: } 1 / 14 \\
\text { Necrotic purpura: } 1 / 14\end{array}$ & $\begin{array}{l}\text { SARS-CoV-2 PCR in } 14 \text { patients: } \\
\text { Positive: } 14 / 14(100 \%)\end{array}$ & $\begin{array}{l}\text { Inflammatory lesions }=7 / 14 \text { : } \\
\text { Exanthema }(n=4) \\
\text { Chicken pox-like virus }(n=2) \\
\text { Cold urticaria }(n=1) \\
\text { Vascular lesions }=7 / 14 \text { : } \\
\text { Violaceous macules with } \\
\text { "porcelain-like" appearance } \\
(n=1) \\
\text { Livedo ( } n=1) \\
\text { Non-necrotic purpura }(n=1) \\
\text { Necrotic purpura }(n=1) \\
\text { Chilblain appearance with Raynaud's } \\
\text { phenomenon }(n=1) \\
\text { Chilblain }(n=1) \\
\text { Eruptive cherry angioma }(n=1)\end{array}$ & NA \\
\hline $\begin{array}{l}\text { de Masson } \\
\text { et al. }(2020)^{15}\end{array}$ & $\begin{array}{l}\text { Total population: } 277 \text { patients } \\
\text { Age, mean (range): } 27 \text { years (2-98) } \\
\text { "Half of patients were male" } \\
\text { Skin lesions: } 277 / 277(100 \%) \\
\text { Petechial: } 7 / 277(3 \%) \text { : } \\
\text { Age, mean (range): } 21 \text { years }(5-70) \\
5 \text { male }(71.4 \%), 2 \text { female }(28.6 \%)\end{array}$ & $\begin{array}{l}\text { SARS-CoV-2 PCR completed } \\
\text { in } 34(12 \%) \text { patients: } \\
\text { Positive: } 25 / 34(73.5 \%) \\
\text { Negative: } 9 / 34 \text { negative }(26.5 \%)\end{array}$ & $\begin{array}{l}\text { Classification: } \\
\text { Morbilliform lesions ( } n=25,9 \%) \\
\text { Acral lesions ( } n=142,51 \%) \\
\text { Vesicular lesions }(n=41,15 \%) \\
\text { Livedo reticularis }(n=4,1 \%) \\
\text { Urticarial lesions }(n=26,9 \%) \\
\text { Petechial lesions ( } n=7,3 \%) \\
\text { Other types of lesions }(n=41,15 \%)\end{array}$ & $\begin{array}{l}\text { Location of petechial lesions: } \\
\text { Diffuse }(n=3,43 \%) \\
\text { Acral }(n=2,29 \%) \\
\text { Limbs }(n=2,29 \%)\end{array}$ \\
\hline $\begin{array}{l}\text { Docampo-Simon } \\
\text { et al. }(2020)^{35}\end{array}$ & $\begin{array}{l}\text { Total population: } 58 \text { patients } \\
\text { Age, median (range): } 14 \text { years } \\
\text { ( } 3 \text { months-85 yrs) } \\
29 \text { male }(50 \%), 29 \text { female }(50 \%) \\
\text { Skin lesions: } 58 / 58(100 \%) \\
\text { Purpuric: } 3 / 58(5.17 \%)\end{array}$ & $\begin{array}{l}\text { SARS-CoV-2 PCR performed } \\
\text { in } 39(67 \%) \text { patients: } \\
\text { Positive: } 1 / 39(2.56 \%) \\
\text { Negative: } 38 / 39(97.4 \%)\end{array}$ & $\begin{array}{l}\text { Classification: } \\
\text { Chilblain-like lesions ( } n=42) \\
\text { Purpuric }(n=3) \\
\text { Maculopapular }(n=3) \\
\text { Vesiculobullous }(n=3) \\
\text { Eczematous }(n=3 \\
\text { Paronychia }(n=2) \\
\text { Ulcer }(n=1) \\
\text { Desquamation }(n=1)\end{array}$ & $\begin{array}{l}\text { Location of ALL lesions: } \\
\text { Hands }(n=9,15.5 \%) \\
\text { Feet }(n=36,62.1 \%) \\
\text { Hands and Feet } \\
(n=13,22.4 \%)\end{array}$ \\
\hline $\begin{array}{l}\text { Magro } \\
\quad \text { et al. }(2020)^{53}\end{array}$ & $\begin{array}{l}\text { Total population: } 5 \text { patients } \\
\text { Skin lesions: } 3 / 5(60 \%) \\
1 \text { male, age } 32 \text { years old } \\
2 \text { females, ages } 40 \text { and } 66 \text { years } \\
\text { Purpuric skin rash: } 3 / 3(100 \%)\end{array}$ & $\begin{array}{l}\text { SARS-CoV-2 PCR: } \\
\text { Positive: } 5 / 5(100 \%)\end{array}$ & $\begin{array}{l}\text { Classification: } \\
\text { Purpuric lesions }(n=3) \\
\text { Description: } \\
\text { Retiform purpura }(33.3 \%) \\
\text { Dusky purpuric patches }(33.3 \%) \\
\text { Mildly purpuric reticulated } \\
\quad \text { eruptions }(33.3 \%)\end{array}$ & $\begin{array}{l}\text { Location of purpuric lesions: } \\
\text { Buttocks (retiform purpura) } \\
\text { Palms and soles (dusky } \\
\text { purpuric patches) } \\
\text { Chest, legs, and arms (mildly } \\
\text { purpuric reticulated } \\
\text { eruptions) }\end{array}$ \\
\hline $\begin{array}{l}\text { Rubio-Muniz } \\
\quad \text { et al. }(2020)^{14}\end{array}$ & $\begin{array}{l}\text { Total population: } 34 \text { patients } \\
\text { Age, mean (range): } 54.5 \text { years }(31-66) \\
14 \text { male }(41 \%), 20 \text { female }(59 \%) \\
\text { Skin lesions: } 34 / 34(100 \%) \\
\text { Palpable purpura: } 4 / 34(11.8 \%) \\
\text { Age, mean (range): } 62 \text { years (57-69) } \\
1 \text { male }(25 \%), 3 \text { female }(75 \%)\end{array}$ & $\begin{array}{l}\text { SARS-CoV-2 PCR: } \\
\text { Positive PCR: } 17 / 34(50 \%) \\
\text { Negative PCR: } 9 / 34(26 \%) \\
\text { Radiological diagnosis: } \\
\text { Confirmed: } 8 / 34(23.5 \%), 4 \text { with } \\
\text { negative PCR } \\
\text { Total confirmed: } 25 / 34(73.5 \%) \\
\text { Patients with palpable purpura: } \\
\text { Positive RT-PCR: } 2 / 4(50 \%) \\
\text { Radiological diagnosis: } 1 / 4 \text { (25\%) } \\
\text { Suspected: } 1 / 4(25 \%)\end{array}$ & $\begin{array}{l}\text { Classification: } \\
\text { Maculopapular ( } n=10) \\
\text { Pseudo-chilblain }(n=9) \\
\text { Targetoid lesions }(n=5) \\
\text { Palpable purpura ( } n=4 \text { of which } \\
2 \text { cases are with vesicular lesions) } \\
\text { Acute urticaria ( } n=3) \\
\text { Vesicular ( } n=2 \text {, these also have } \\
\text { palpable purpura) } \\
\text { Remaining } 3 \text { cases include livedo } \\
\text { reticularis, urticarial exanthem, } \\
\text { and prurigo lesions. }\end{array}$ & $\begin{array}{l}\text { A figure displayed palpable } \\
\text { purpara lesions on the lower } \\
\text { extremities of a patient } \\
\text { suffering from COVID-19 } \\
\text { pneumonia. }\end{array}$ \\
\hline
\end{tabular}

RT-PCR, reverse transcription polymerase chain reaction. 


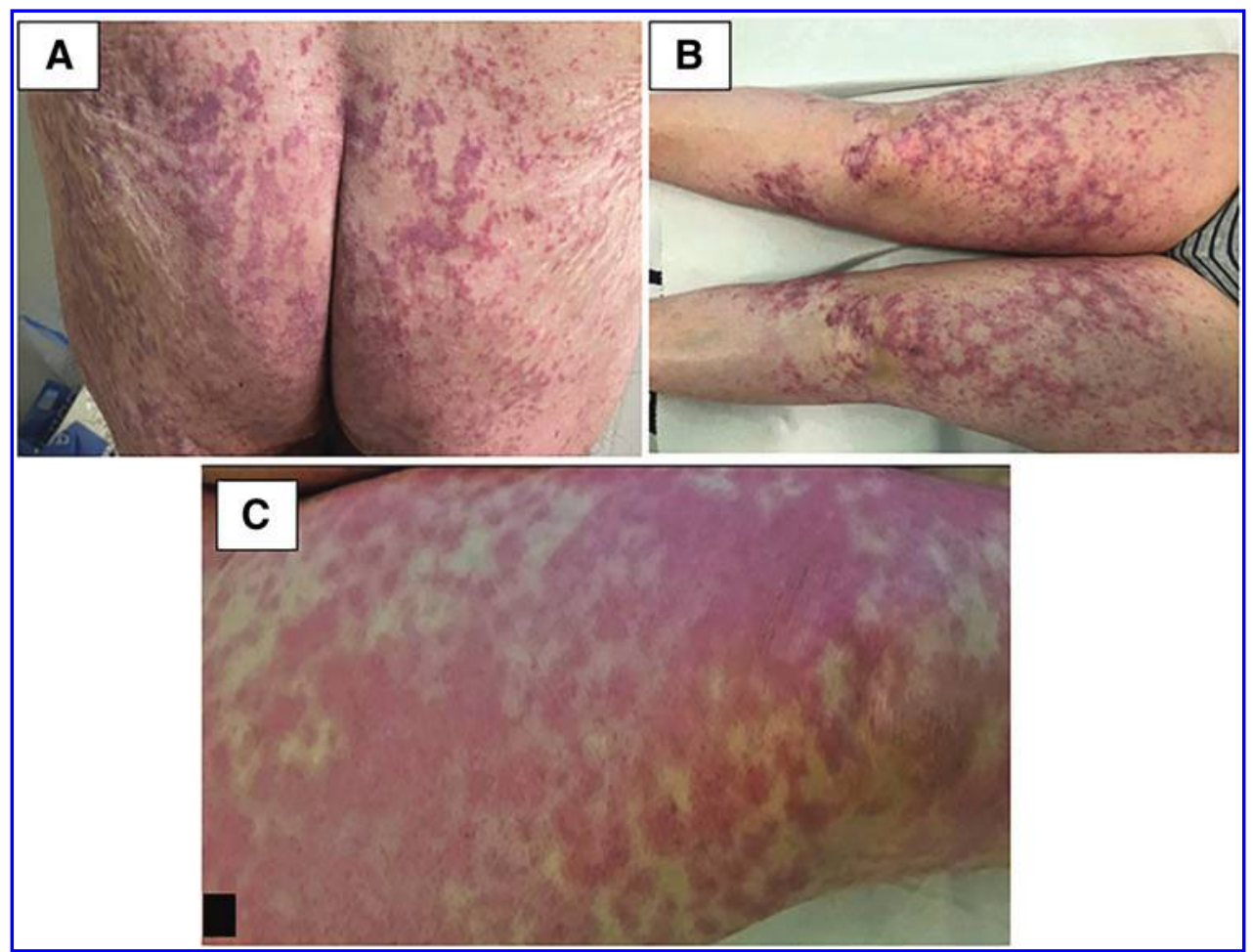

Figure 7. Examples of livedoid rash seen during the COVID-19 pandemic. (A) Livedoid lesions, often a product of vasculopathy, present on patient's buttocks. (B) Lesions affecting the patient's lower extremities (thighs) are characterized as livedo racemose like. (C) Livedoid eruption present in an intubated patient with severe systemic and pulmonary symptoms associated with COVID-19. Reproduced with permission from John Wiley and sons (A, B); Wolters Kluwer Health, Inc. (C). The following original reports are credited: Galván Casas et $a .^{52}$; Marzano et al. ${ }^{50}$; Gianotti et al. ${ }^{18}$

trunk, flexor surface of forearms, dorsal hand, and dorsal foot. ${ }^{11,44,55}$ These lesions occurred at the same time as other Covid-19 symptoms and primarily appeared in elderly patients with more severe infections. Duration of this lesion was 9.4 days on average. According to a Spanish case series, the mortality rate among patients with livedoid lesions was the highest of all cutaneous manifestations at $10 \% .^{11}$

While the molecular mechanisms of livedoid eruptions are not yet known, a few theories have been discussed. One of these theories is the relationship of hypercoagulability to Covid-19 infections. A retrospective study of 183 patients with Covid-19 showed that nonsurvivors of the study had higher D-dimer and fibrin degradation product levels, in addition to a longer prothrombin time, suggesting that patients with severe COVID-19, similar to those presenting with livedoid lesions, are at a greater risk for coagulation abnormalities. ${ }^{56}$ Manalo et al. hypothesize that DIC and macrothromboses may be associated to the production of LR in more severe cases of infection. In less severe cases of COVID-19, microthrombi formation created by inflammatory cytokines or ACE2 entry into cells may be impli- cated in the production of LR. ${ }^{57}$ Other significant hypotheses about the potential causes of livedoid lesions have been provided in Table 9 .

\section{Multisystem inflammatory syndrome in children}

Throughout the pandemic, children have remained relatively unscathed from severe COVID-19related complications. This remained true until late April 2020, when multiple reports of critically ill children exhibiting severe inflammatory syndrome with Kawasaki disease-like features were first made public in the United Kingdom. ${ }^{58}$ Verdoni et al. later reported that within a short time span, they had witnessed a 30-fold increased incidence of Kawasaki-like disease primarily in children who tested positive for antibodies against SARS-CoV-2. ${ }^{59}$ Since then, cases of this new and serious health condition labeled as MIS-C have grown incrementally throughout the world (Fig. 8). MIS-C is said to exhibit overlapping features of Kawasaki disease and toxic shock syndrome in a minute number of children exposed to COVID-19. ${ }^{58}$ However, it is important to note that MIS-C also has a few noticeable differences when compared to Kawasaki disease such as an older onset (older children and adoles- 
Table 6. Demographic and clinical details of livedoid lesions observed in COVID-19 patients

\begin{tabular}{|c|c|c|c|c|}
\hline $\begin{array}{l}\text { Article } \\
\text { and Year }\end{array}$ & $\begin{array}{c}\text { Number of Patients, } \\
\text { Age, Gender }\end{array}$ & $\begin{array}{c}\text { Suspected or } \\
\text { Confirmed COVID-19 }\end{array}$ & COVID-19 Cutaneous Manifestations & $\begin{array}{c}\text { Anatomical Location } \\
\text { of Cutaneous } \\
\text { Manifestations }\end{array}$ \\
\hline $\begin{array}{l}\text { Bouaziz } \\
\text { et al. }(2020)^{44}\end{array}$ & $\begin{array}{l}\text { Total population: } 14 \text { patients } \\
\text { Age/gender NR } \\
\text { Skin lesions: } 14 / 14(100 \%) \\
\text { Livedo: } 1 / 14(7.1 \%)\end{array}$ & $\begin{array}{l}\text { SARS-CoV-2 PCR in } 14 \text { patients: } \\
\text { Positive: } 14 / 14(100 \%)\end{array}$ & $\begin{array}{l}\text { Inflammatory lesions }=7 / 14 \text { : } \\
\text { Exanthema }(n=4) \\
\text { Chicken pox-like virus }(n=2) \\
\text { Cold urticaria }(n=1) \\
\text { Vascular lesions }=7 / 14 \text { : } \\
\text { Violaceous macules with "porcelain-like" } \\
\text { appearance }(n=1) \\
\text { Livedo }(n=1) \\
\text { Non-necrotic purpura }(n=1) \\
\text { Necrotic purpura }(n=1) \\
\text { Chilblain appearance with Raynaud's } \\
\text { phenomenon }(n=1) \\
\text { Chilblain }(n=1) \\
\text { Eruptive cherry angioma }(n=1)\end{array}$ & $\begin{array}{l}\text { Trunk } \\
\text { Digital involvement i } \\
\quad \mathrm{n} \text { the feet }\end{array}$ \\
\hline $\begin{array}{l}\text { Cordoro } \\
\quad \text { et al. }(2020)^{55}\end{array}$ & $\begin{array}{l}\text { Total population: } 6 \text { patients: } \\
\text { Pediatric population, } \\
\text { range } 12-17 \\
5 \text { male }(83.3 \%) \text {, } \\
1 \text { female }(16.6 \%) \\
\text { Skin lesions: } 6 / 6(100 \%) \\
\text { Livedo/necrosis: } 3 / 6(50 \%)\end{array}$ & $\begin{array}{l}\text { SARS-CoV-2 PCR: All negative } \\
\text { Serology: IgM and lgG negative }\end{array}$ & $\begin{array}{l}\text { Classification: } \\
\text { Acral perniosis-like lesions } \\
\text { Livedo reticularis } \\
\text { Description: } \\
\text { Red to violaceous macules and dusky } \\
\text { purpuric plaques scattered mid- } \\
\text { and distal parts of the toes; severely } \\
\text { affected digits with edematous, } \\
\text { superficial bullae and focal hemorrhagic } \\
\text { crust; petechial and purpuric macules } \\
\text { on heels, soles, and dorsolateral foot; } \\
\text { few cases with erythematous macule } \\
\text { around the distal nail folds; half the } \\
\text { cases with livedo reticularis of flexor } \\
\text { surface of forearms, dorsal hand, } \\
\text { and dorsal feet }\end{array}$ & $\begin{array}{l}\text { Flexor surface of forearm, } \\
\text { dorsal hand, and } \\
\text { dorsal foot }\end{array}$ \\
\hline $\begin{array}{l}\text { de Masson } \\
\text { et al. }(2020)^{15}\end{array}$ & $\begin{array}{l}\text { Total population: } 277 \text { patients } \\
\text { Age, mean (range): } \\
27 \text { years (2-98) } \\
\text { "Half of patients were male" } \\
\text { Skin lesions: } 277 / 277(100 \%) \\
\text { Livedo reticularis: } 4 / 277(1.4 \%)\end{array}$ & $\begin{array}{l}\text { SARS-CoV-2 PCR completed } \\
\text { in } 34(12 \%) \text { patients: } \\
\text { Positive: } 25 / 34(73.5 \%) \\
\text { Negative: } 9 / 34(26.5 \%)\end{array}$ & $\begin{array}{l}\text { Classification: } \\
\text { Morbilliform lesions ( } n=25,9 \%) \\
\text { Acral lesions }(n=142,51 \%) \\
\text { Vesicular lesions }(n=41,15 \%) \\
\text { Livedo reticularis }(n=4,1 \%) \\
\text { Urticarial lesions }(n=26,9 \%) \\
\text { Petechial lesions }(n=7,3 \%) \\
\text { Other types of lesions }(n=41,15 \%)\end{array}$ & $\begin{array}{l}\text { Morbilliform—trunk, limbs, } \\
\text { and face } \\
\text { Acral—hands and feet } \\
\text { Vesicular—trunk and limbs } \\
\text { Livedo—N/A } \\
\text { Urticarial—trunk, limbs, } \\
\text { and face } \\
\text { Petechial—diffuse, acral, } \\
\text { and limbs } \\
\text { Other-trunk, limbs, and face }\end{array}$ \\
\hline $\begin{array}{l}\text { Galvan } \\
\quad \text { et al. }(2020)^{11}\end{array}$ & $\begin{array}{l}\text { Total population: } 429 \text { patients } \\
54 \text { patients excluded, } 375 \text { patients } \\
\text { in study, } \\
153 \text { males ( } 40.8 \%), 222 \text { females } \\
(59.2 \%) \\
\text { Skin lesions: } 375 / 375(100 \%) \\
\text { Livedo/necrosis: } 21 / 375(6 \%) \\
\text { Age, mean (SD): } 63.1 \text { years (17.3) } \\
11 \text { male ( } 52.4 \%), 10 \text { female }(47.6 \%)\end{array}$ & $\begin{array}{l}\text { Laboratory confirmation } \\
\text { of SARS-CoV-2 } \\
\text { Patients with skin lesions: } \\
\text { Confirmed: } 234 / 375(62.4 \%) \\
\text { Suspected: } 141 / 375(37.6 \%) \\
\text { Livedo/necrosis patients: } \\
\text { Confirmed 17/21: }(81 \%) \\
\text { Suspected: } 4 / 21(19 \%)\end{array}$ & $\begin{array}{l}\text { Classification: } \\
\text { Vesicles/pustules (pseudo-chilblain) (19\%) } \\
\text { Vesicular eruptions (9\%) } \\
\text { Urticarial lesions (19\%) } \\
\text { Maculopapular eruptions (47\%) } \\
\text { Livedo or necrosis (6\%) }\end{array}$ & Truncal or acral ischemia \\
\hline $\begin{array}{l}\text { Rubio-Muniz } \\
\text { et al. }(2020)^{14}\end{array}$ & $\begin{array}{l}\text { Total population: } 34 \text { patients } \\
\text { Age, mean (range): } \\
54.5 \text { years }(31-66) \\
14 \text { male }(41 \%), 20 \text { female }(59 \%) \\
\text { Skin lesions: } 34 / 34(100 \%) \\
\text { Livedo: } 1 / 34(2.94 \%)\end{array}$ & $\begin{array}{l}\text { SARS-CoV-2 PCR: } \\
\text { Positive PCR: } 17 / 34(50 \%) \\
\text { Negative PCR: } 9 / 34(26 \%) \\
\text { Radiological diagnosis: } \\
\text { Confirmed: } 8 / 34(23.5 \%), 4 \text { with } \\
\text { negative PCR } \\
\text { Total confirmed: } 25 / 34(73.5 \%)\end{array}$ & $\begin{array}{l}\text { Classification: } \\
\text { Maculopapular ( } n=10) \\
\text { Pseudo-chilblain }(n=9) \\
\text { Targetoid lesions }(n=5) \\
\text { Palpable purpura ( } n=4 \text {, of which } 2 \text { cases } \\
\text { are with vesicular lesions) } \\
\text { Acute urticaria ( } n=3) \\
\text { Vesicular ( } n=2 \text {, these also have palpable } \\
\text { purpura) } \\
\text { Remaining } 3 \text { cases include livedo reticularis, } \\
\text { urticarial exanthem, and prurigo lesions. }\end{array}$ & $\mathrm{N} / \mathrm{A}$ \\
\hline
\end{tabular}


cents), abdominal symptoms, and a greater number of cases with heart conditions. ${ }^{60}$

Diagnostic criteria for Kawasaki disease involve a diffuse polymorphic rash, including maculopapular, erythema multiforme like, or diffuse erythroderma. ${ }^{61}$ Similar erythematous polymorphic rashes are predominantly seen in patients reported to have MIS-C. ${ }^{59}$ Whittaker et al. reported a case series in which 30 of the 58 patients diagnosed with MIS-C had erythematous rashes, with one patient having additional purpuric manifestations. ${ }^{62} \mathrm{~A}$ retrospective chart review conducted by Miller et al. likewise discovered rashes present in 31 out of 44 patients; this was the third most common symptom in patients with MIS-C after fever and gastrointestinal symptoms. ${ }^{63}$ One study comprised 35 patients positive for MIS-C and described the location of rash seen in 13 patients (37\%) as being variably distributed, including limbs, face, and generalized. ${ }^{64}$ Many other studies found rash to be common in MIS-C patients; however, detailed analysis on the type of rash, onset, and duration was not mentioned $^{59,65-73}$ (Table 7). Additional research is needed to study and clarify the skin manifestations of MIS-C and its association with COVID-19.

Etiology of Kawasaki disease is largely unknown, although a genetic predisposition has been established. Similarly, the molecular mechanisms behind MIS-C's cutaneous manifestations and their relationship to COVID-19 are also unidentified..$^{74}$

\section{DISCUSSION}

The COVID-19 pandemic, a consequence of the recent emergence of SARS-CoV-2 in humans, continues to spread rapidly resulting in an ongoing global health crisis. Despite the daily emergence of new data, much remains relatively unknown in regards to COVID-19's clinical characteristics, including its cutaneous manifestations. As a novel strain of the Coronavirus family, which is most commonly known for its respiratory tract infections, SARS-CoV-2 has been associated with many viral exanthems. Although a few respiratory viruses have been associated with cutaneous manifestations in the past, ${ }^{47}$ these rashes are uncharacteristic of the Coronavirus family. ${ }^{75}$ COVID-19's cutaneous manifestations can be divided into two categories, either inflammatory exanthems or vascular lesions. ${ }^{7}$ Knowledge of the changes in skin morphology related to COVID-19 may be instrumental in helping physicians diagnosis and treat future COVID-19 patients.

Patterns of COVID-19 exanthems include maculopapular, urticarial, vesicular, and MIS-C rash. Among these exanthems, maculopapular rashes

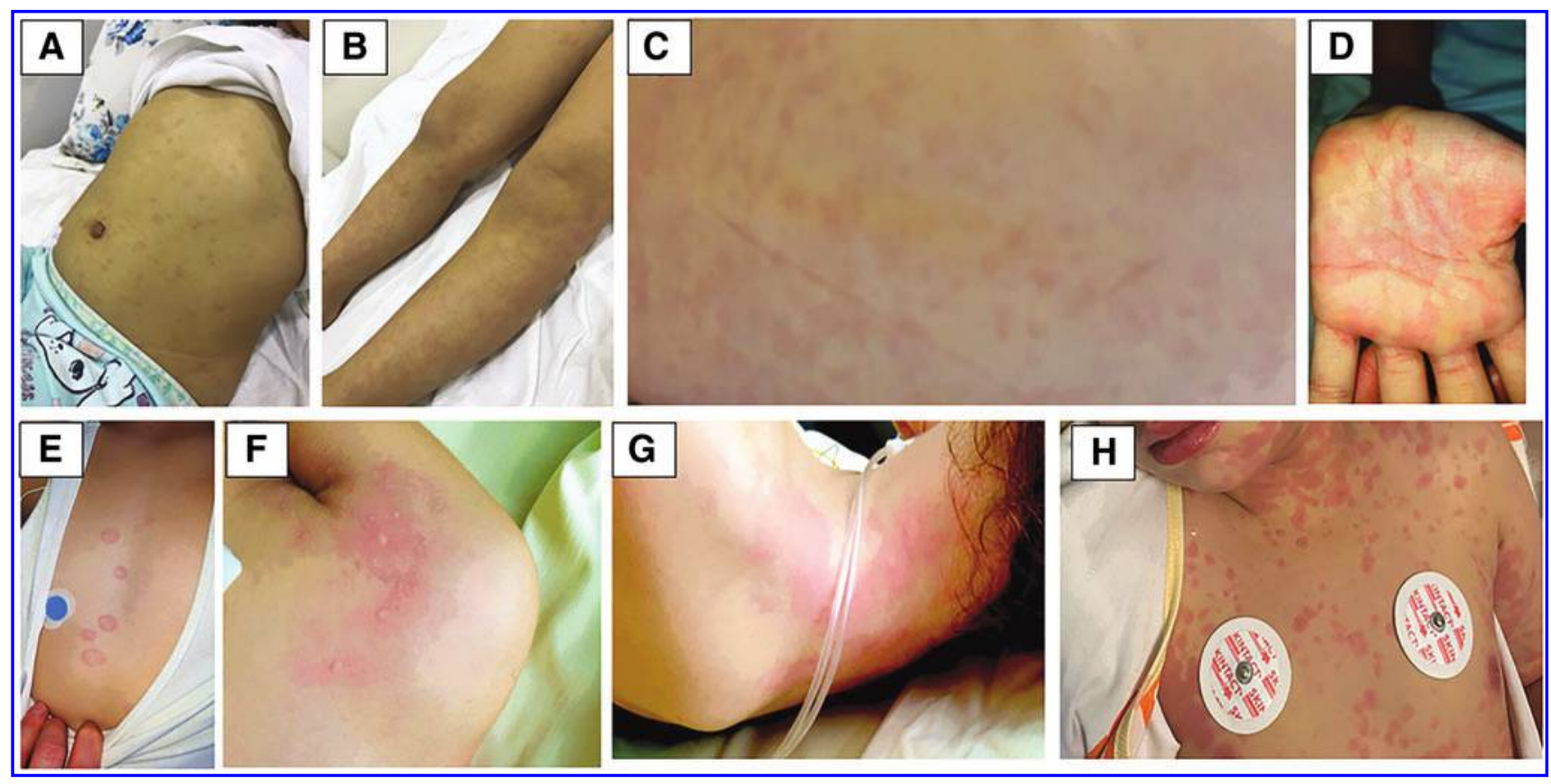

Figure 8. Examples of maculopapular rash seen in MIS-C patients during the COVID-19 pandemic. (A, B) Maculopapular/morbilliform rash, described as polymorphous, present on 3-year old's trunk and lower extremities. (C) Maculopapular rash present in a 12-year-old patient with Kawa-COVID-19. (D-G) Maculopapular lesions present in a 12-year-old girl with MIS-C. (H) Skin rash present on 5-year-old patient with MIS-C. MIS-C, multisystem inflammatory syndrome in children. Reproduced with permission from John Wiley and sons (A, B, H), BMJ Publishing Group Ltd. (C) and Wolters Kluwer Health, Inc. (D-G). The following original reports are credited: Yozgat et al..$^{72}$; Pouletty et al. ${ }^{67}$; Belhadjer et al. ${ }^{65}$; Bahrami et al. ${ }^{73}$ 
Table 7. Demographic and clinical details of multisystem inflammatory syndrome in children (Kawasaki like) lesions observed in COVID-19 patients

\begin{tabular}{|c|c|c|c|}
\hline $\begin{array}{l}\text { Article } \\
\text { and Year }\end{array}$ & $\begin{array}{l}\text { Number of Patients, } \\
\text { Age, Gender }\end{array}$ & $\begin{array}{c}\text { Suspected or } \\
\text { Confirmed COVID-19 }\end{array}$ & COVID-19 Cutaneous Manifestations \\
\hline $\begin{array}{l}\text { Belhadjer } \\
\quad \text { et al. }(2020)^{65}\end{array}$ & $\begin{array}{l}\text { Total population: } 35 \text { patients } \\
\quad \text { Age, median (range): } 10 \text { years }(2-16) \\
18 \text { male }(51 \%), 17 \text { female }(49 \%) \\
\text { Skin rash: } 20 / 35(57 \%)\end{array}$ & $\begin{array}{l}\text { Positive SARS-CoV-2 PCR: } 14 / 35(40 \%) \\
\text { Positive serology: } 30 / 35(86 \%) \\
\text { CT chest: typical for infection in } 2 \text { patients } \\
\text { Total confirmed }=31 / 35(88.5 \%)\end{array}$ & $\begin{array}{l}\text { Classification: } \\
\text { Unspecified MIS-C rash }(n=19) \\
\text { Description: } \\
\text { Maculopapular rash seen in one patient, } \\
\text { 12-year-old female }\end{array}$ \\
\hline $\begin{array}{l}\text { Cheung } \\
\text { et al. }(2020)^{69}\end{array}$ & $\begin{array}{l}\text { Total population: } 17 \text { patients } \\
\quad \text { Age, median (range): } 8 \text { years (1.8-16) } \\
8 \text { male }(47 \%), 9 \text { female }(53 \%) \\
\text { Skin rash: } 12 / 17 \text { (71\%) } \\
\quad \text { Skin desquamation: } 3 / 17(18 \%)\end{array}$ & $\begin{array}{l}\text { Positive SARS-CoV-2 PCR: } 8 \\
\text { Positive serology: } 9 \\
\text { Confirmed: } 17 / 17(100 \%)\end{array}$ & $\begin{array}{l}\text { Classification: } \\
\quad \text { Unspecified MIS-C rash }(n=12)\end{array}$ \\
\hline $\begin{array}{l}\text { Grimaud } \\
\quad \text { et al. }(2020)^{68}\end{array}$ & $\begin{array}{l}\text { Total population: } 20 \text { patients } \\
\quad \text { Age, median (range): } 10 \text { year }(2.9-15) \\
10 \text { male }(50 \%), 10 \text { female }(50 \%) \\
\text { Skin rash: } 10 / 20(50 \%)\end{array}$ & $\begin{array}{l}\text { Positive SARS-CoV-2 PCR: } 12 / 20(60 \%) \\
\text { Positive serology: } 15 / 20(75 \%) \\
\text { Confirmed: } 19 / 20(95 \%) \\
1 \text { patient with negative PCR and serology } \\
\text { however, chest CT chest typical for infection. }\end{array}$ & $\begin{array}{l}\text { Classification: } \\
\quad \text { Unspecified MIS-C rash }(n=10)\end{array}$ \\
\hline $\begin{array}{l}\text { Hameed } \\
\text { et al. }(2020)^{64}\end{array}$ & $\begin{array}{l}\text { Total population: } 35 \text { patients } \\
\text { Age, median (IOR): } 11 \text { years ( } 8) \\
\text { (4/35 patients under the age of } 5 \text { years) } \\
27 \text { male }(77 \%), 8 \text { female }(23 \%) \\
\text { Skin rash: } 13 / 35(37 \%)\end{array}$ & $\begin{array}{l}\text { SARS-CoV-2 PCR: } 35 / 35 \text { negative } \\
\text { Serology performed in } 30 \text { patients: } \\
27 / 30 \text { positive }(90 \%) \\
3 / 30 \text { negative }(10 \%)\end{array}$ & Unspecified MIS-C rash $(n=13)$ \\
\hline $\begin{array}{l}\text { Kaushik } \\
\quad \text { et al. }(2020)^{71}\end{array}$ & $\begin{array}{l}\text { Total population: } 33 \text { patients } \\
\text { Age, median (IQR): } 10 \text { years (6-13) } \\
20 \text { male }(60.6 \%), 13 \text { female }(39.4 \%) \\
\text { Skin rash: } 14 / 33(42 \%)\end{array}$ & $\begin{array}{l}\text { Positive SARS-CoV-2 PCR: 11/33 (33\%) } \\
\text { Positive serology: } 27 / 33(81 \%) \\
\text { RT-PCR and serology positive: } 6 \text { (18\%) }\end{array}$ & Unspecified MIS-C rash $(n=14)$ \\
\hline $\begin{array}{l}\text { Miller } \\
\quad \text { et al. }(2020)^{63}\end{array}$ & $\begin{array}{l}\text { Total population: } 44 \text { patients } \\
\text { Age, median (range): } 7.3 \text { years } \\
\text { (7 months-20 years) (SD 4.98) } \\
20 \text { male }(45 \%), 24 \text { female }(55 \%) \\
\text { Skin rash: } 31 / 44(70.5 \%)\end{array}$ & $\begin{array}{l}\text { SARS-CoV-2 PCR in } 44 \text { patients: } \\
\text { Positive: } 15(34.1 \%) \\
\text { Negative: } 25(56.8 \%) \\
\text { Indeterminate: } 4(9.1 \%) \\
\text { Serology completed in } 32 \text { patients: } \\
\text { Positive: } 31(96.9 \%) \\
\text { Inderterminate: } 1(3.1 \%)\end{array}$ & Unspecified MIS-C rash $(n=44)$ \\
\hline $\begin{array}{l}\text { Pouletty } \\
\text { et al. }(2020)^{67}\end{array}$ & $\begin{array}{l}\text { Total population: } 16 \text { patients } \\
\text { Age, median (IOR): } 10 \text { years (4.7 to } 12.5) \\
8 \text { male (50\%), } 8 \text { female (50\%) } \\
\text { Skin rash: } 13 / 16 \text { ( } 81 \%)\end{array}$ & $\begin{array}{l}\text { Positive SARS-CoV-2 PCR: } 11 / 16(69 \%) \\
\text { Positive serology: } 7 / 8 \text { ( } 87 \%) \\
\text { Negative using both PCR and serology: } 2\end{array}$ & $\begin{array}{l}\text { Classification: } \\
\text { Unspecified MIS-C rash }(n=13) \\
\text { Description: } \\
\text { Diffuse skin rash }(n=13) \\
\text { Maculopapular rash }(n=1) \\
\text { Rash/edema of hands and feet }(n=11)\end{array}$ \\
\hline $\begin{array}{l}\text { Riollano-Cruz } \\
\quad \text { et al. }(2020)^{70}\end{array}$ & $\begin{array}{l}\text { Total population: } 15 \text { patients } \\
\text { Age, mean (range): } 12 \text { years (3-20) } \\
11 \text { male }(73 \%), 4 \text { female }(27 \%) \\
\text { Skin rash: } 7 / 15(47 \%)\end{array}$ & $\begin{array}{l}\text { Positive SARS-CoV-2 PCR: } 9 / 15(60 \%) \\
\text { Positive serology: } 15 / 15(100 \%) \\
\text { Total confirmed } 15 / 15(100 \%)\end{array}$ & $\begin{array}{l}\text { Classification: } \\
\quad \text { Unspecified MIS-C rash }(n=7)\end{array}$ \\
\hline $\begin{array}{l}\text { Toubiana } \\
\text { et al. }(2020)^{66}\end{array}$ & $\begin{array}{l}\text { Total population: } 21 \text { patients } \\
\text { Age, median (range): } 7.9 \text { years } \\
(3.7-16.6) \\
9 \text { male }(43 \%), 12 \text { female }(57 \%) \\
\text { Skin rash: } 16 / 21(76 \%)\end{array}$ & $\begin{array}{l}\text { Positive RT-PCR: } 8 / 21(38 \%) \\
\text { Positive lgG serology: 19/21 (90.5\%) } \\
\text { Total confirmed 19/21 (90.5\%) }\end{array}$ & $\begin{array}{l}\text { Classification: } \\
\text { Unspecified MIS-C rash }(n=16) \\
\text { Description: } \\
\text { Polymorphous skin rash }(n=16)\end{array}$ \\
\hline $\begin{array}{l}\text { Verdoni } \\
\quad \text { et al. }(2020)^{59}\end{array}$ & $\begin{array}{l}\text { Total population: } 10 \text { patients } \\
\text { Age, mean (SD): } 7.5 \text { years }(3.5) \\
7 \text { male }(70 \%), 3 \text { female }(30 \%) \\
\text { Skin rash: } 8 / 10(80 \%)\end{array}$ & $\begin{array}{l}\text { Positive SARS-CoV-2 PCR: 2/10 (20\%) } \\
\text { Positive serology: } 8 / 10(80 \%)\end{array}$ & $\begin{array}{l}\text { Classification: } \\
\text { Unspecified MIS-C rash }(n=8) \\
\text { Description: } \\
\text { Polymorphous skin rash }(n=8)\end{array}$ \\
\hline $\begin{array}{l}\text { Whittaker } \\
\text { et al. }(2020)^{62}\end{array}$ & $\begin{array}{l}\text { Total population: } 58 \text { patients } \\
\text { Age, median (IOR): } 9 \text { years }(5.7-14) \\
25 \text { male }(43 \%), 33 \text { female }(57 \%) \\
\text { Skin rash: } 30 / 58(52 \%)\end{array}$ & $\begin{array}{l}\text { Positive SARS-CoV-2 PCR: } 15 / 58(26 \%) \\
\text { for respiratory PCR only } \\
\text { Positive IgG antibody: } 40 / 46(87 \%) \\
\text { Any SARS-CoV2 PCR or IgG: } 45 / 58(78 \%) \\
\text { Patients with erythematous rash: } \\
\text { Positive: } 21 / 30(70 \%) \\
\text { Negative: } 9 / 30(30 \%)\end{array}$ & $\begin{array}{l}\text { Erythematous rash }(n=30) \\
\text { Purpuric features }(n=1)\end{array}$ \\
\hline
\end{tabular}

MIS-C, multisystem inflammatory syndrome in children. 
appear to be the most common followed by urticarial, vesicular, and MIS-C rashes. Maculopapular and urticarial exanthems are more commonly seen in middle-aged to older patients and are typically associated with severe COVID-19 infections. Rash onset of both varies between studies. Both are reported to be unhelpful in diagnosis as the rash can be due to possible drug-induced dermatological adverse reactions. Onset of vesicular eruptions also vary, while the majority are seen after the presentation of systemic symptoms, few cases have noted onset prior to systemic symptoms. The rash was noted frequently among middle-aged patients.

Of note, this type of exanthem is commonly seen in other viral infections, such as varicella zoster and herpes simplex. MIS-C is a novel and severe disease seen in children; therefore, not much is known concerning its clinical characteristics. Despite the lack of information, published data show that skin manifestations appear in a majority of MIS-C patients. There is also a possible correlation with Kawasaki's disease along with an association involving immunoglobulins as a treatment modality.

Vascular lesions associated with COVID-19 are characterized into pseudo-chilblain, petechiae/ purpura, or livedoid. Chilblain-like lesions are very similar to pernio lesions that occur after exposure to very cold temperatures; however, unlike pernio, these lesions appear in warmer climates. These lesions are commonly located on the fingers and toes of younger patients and are associated with less severe COVID-19 infections. Onset of pseudochilblain lesions is typically after the onset of COVID-19 systemic symptoms. Petechiae/purpura lesions are more common in middle-aged patients. These lesions have been associated with a greater severity of COVID-19 infection. Studies involving these lesions have described their location as being diffuse, acral, or on distal extremities/ limbs. ${ }^{15,16}$ Livedoid lesions are among the least common skin manifestations seen during the pandemic. They are primarily seen in elderly patients and have been correlated with particularly severe COVID-19 infections. ${ }^{11}$

The pathophysiologic mechanisms behind COVID-19's skin manifestations are not well known; however, many theories have been considered. Maculopapular and urticarial rashes are believed to be due to an adverse reaction to pharmaceutical COVID-19 drugs or overproduction of cytokines triggered by hyperinflammation. ${ }^{12,20}$ Possible molecular mechanisms of chilblain-like lesions are numerous, including "immune dysregulation, vasculitis, vessel thrombosis, or neoangiogensis. ${ }^{44 "}$ Pathogenesis for petechial/purpuric skin lesions involves pauci-inflammatory thrombogenic vasculopathy with extensive deposition of complement components C5b-9 and C4d within the cutaneous microvasculature. Alternative etiology of these skin lesions could be adverse dermatological side effects to medications used for COVID-19. Livedoid's molecular mechanisms are hypothesized as being dependent on the severity of the COVID-19 infection. In more severe infections, livedoid eruptions are thought to be due to DIC and macrothromboses. In less severe COVID-19 infections, these vascular lesions are assumed to be a product of microthrombi formation created by inflammatory cytokines or ACE2 entry into cells. Vesicular lesions are thought to result from "cytokine storm" due to hyperactivity of the immune system. Proposed etiology of MIS-C remains unknown. Finally, it should also be noted that the cutaneous manifestations seen during this pandemic might be a direct effect of the SARS-CoV-2 virus.

Although skin rashes as seen in SARS-CoV-2 are unusual in comparison to other coronaviruses, many respiratory viruses have been associated with cutaneous manifestations (Table 8). Similar to SARS-CoV-2, certain adenovirus serotypes can present with maculopapular, vesicular, or petechial exanthems. ${ }^{47}$ Exanthems due to influenza viruses are extremely rare, seen in only $2-8 \%$ of cases and present more frequently in children compared to adults. ${ }^{47}$ Skin manifestations seen in influenza A are petechial, macular, papular, maculopapular, reticular, or purpuric patterns, while influenza B exanthems are less common and include localized or generalized morbilliform patterns. ${ }^{76}$

Human bocavirus rashes were primarily seen in children and include maculopapular erythema, macular erythema, and petechial exanthema. ${ }^{77,78}$ Nonpolio enteroviruses, such as echovirus and coxsackie virus, are the leading cause of rashes in children, especially during the summer and fall. ${ }^{47}$ Coxsackievirus causes hand-foot-mouth disease (HFMD) and typically presents with diffuse maculopapular or vesicular exanthems along with a fever. ${ }^{47}$ In addition to HFMD, echoviruses can also cause aseptic meningitis and are known to exhibit macular, maculopapular, petechial, or vesicular rashes. ${ }^{47,79}$ Nonpruritic, maculopapular, and transient rashes were located on the trunk and back of some children with human metapneumovirus infections. ${ }^{80}$ Exanthems described as erythematous, maculopapular, and discrete were found to be associated with rhinoviruses, respiratory syncytial virus, and parainfluenza viruses (types $1-3)^{47,81}$ 


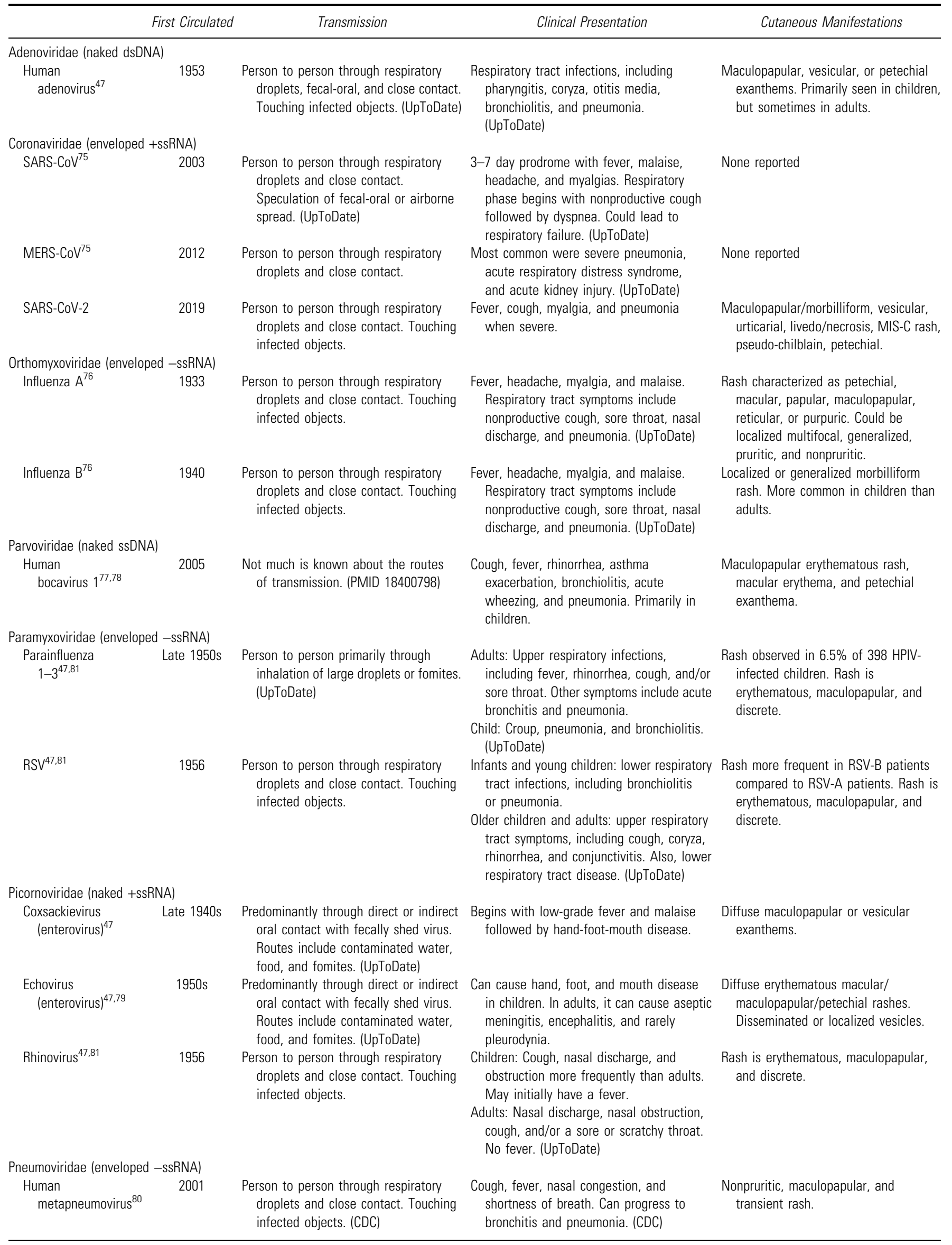

CDC, Centers for Disease Control and Prevention; MERS-CoV, Middle East respiratory syndrome coronavirus; RSV, respiratory syncytial virus. 
Table 9. Potential causes of each dermatological findings

\begin{tabular}{|c|c|}
\hline Dermatologic Finding & Potential Causes \\
\hline Urticaria & $\begin{array}{l}\text { Allergic reaction, anaphylaxis, angioedema, autoimmune disease (e.g., systemic lupus erythematosus), hypereosinophilia, chronic urticaria, } \\
\text { malignancy }\end{array}$ \\
\hline Vesicular & $\begin{array}{l}\text { Varicella zoster (i.e., chicken pox), herpes zoster (i.e., shingles), herpes simplex, Rhus dermatitis (e.g., poison ivy, poison oak, and poison } \\
\text { sumac), pemphigoid }\end{array}$ \\
\hline Petechiae/purpura & $\begin{array}{l}\text { Thrombocytopenia, systemic lupus erythematosus, leukemia, DIC, hemolytic uremic syndrome, thrombotic thrombocytopenic purpura, } \\
\text { vasculitis, vitamin C deficiency }\end{array}$ \\
\hline Distal ischemia/necrosis & Arterial ischemia, DIC, Buerger's disease \\
\hline
\end{tabular}

Reproduced with permission from Elsevier LTD. The following original report is credited: Gottlieb et al. ${ }^{97}$

DIC, disseminated intravascular coagulation.

So far, we have discussed about the virusinduced or drug-induced skin lesions seen in patients infected with SARS-CoV-2. However, this pandemic has silently resulted in additional cutaneous complications, although indirectly through the use of PPE (Fig. 9). These complications include pressure injury, contact dermatitis, urticaria, skin dryness, and aggravation of existing skin diseases. ${ }^{31} \mathrm{PPE}$ refers to wearable personal items used to protect against accidental injuries and occupational hazards. ${ }^{82}$ Due to the possible asymptomatic transmission of SARS-CoV-2 among unknowing individuals, the widespread use of PPE has become mandatory for the reduction of infection rates and prevention of viral spread, especially among frontline health care personnel. These individuals must protect both themselves from occupational hazards and their most vulnerable patients by wearing multiple types of PPE equipment, including goggles/disposable face shields, N95 respirator masks, protective gowns, and latex gloves.

Despite the overall benefits of wearing PPE, their frequent and prolonged use among health care personnel during the COVID-19 pandemic have been associated with various adverse skin injuries $^{83}$ (Fig. 9). PPE-related skin complications are of serious concern since broken cutaneous barriers can create an opening for potential COVID-19 infections and increase contamination by inadvertently spreading the virus. ${ }^{84}$ In the following section, we will discuss the causes and characteristics of skin damage caused by the use of various types of PPE, and introduce the possible measures for skin protection and treatment strategies.

\section{Incidences of PPE-associated skin rashes in COVID-19 pandemic}

A cross-sectional study from China reported the overall prevalence of skin injuries instigated by PPE use in medical personnel to be $42.8 \%$ among 4,306 surveyed participants. Analysis of the survey conducted by Jiang et al. discovered three main types of skin injuries. These were device-related pressure ulcers (DRPU, now known as pressure injuries), moisture-associated skin damage, and skin tears. ${ }^{83}$ Multivariate analysis of risk factors related to PPEinduced skin injuries revealed higher prevalence among males, doctors, participants wearing grade 3 PPE opposed as grade $2 \mathrm{PPE}$, those with daily wearing times greater than 4 hours, age older than 35 years, and finally those who reported heavy sweating. ${ }^{83}$

Another quantitative study out of China surveyed 61 health care workers regularly using PPE (N95 mask, latex gloves, and protective clothing). Adverse skin reactions were discovered in $95.1 \%$ of $\mathrm{N} 95$ mask users, the most majority of which being nasal bridge scarring followed by facial itching and skin damage. Around $88.5 \%$ of health care workers reported cutaneous complications due to latex gloves. The most common skin reactions by these gloves were dry skin and itching followed by rash and chapped skin. Finally, only $67 \%$ of the health care workers reported adverse skin reactions due to protective clothing, the most frequent being dry skin and itching. ${ }^{85}$

Of the cutaneous complications caused by PPE, DRPU/pressure injuries are the most noteworthy. Pressure ulcer/injury is defined by the National Pressure Injury Advisory Panel (NPIAP) as "localized damage to the skin and underlying soft tissue usually over a bony prominence or related to a medical or other device." Before the COVID-19 pandemic, DRPU were primarily seen in patients who were critically ill; however, this pandemic has introduced DRPU as a novel complication resulting in facial injuries among health care personnel wearing PPE. ${ }^{86-88}$ The PPE devices used among medical staff inducing DRPU were 


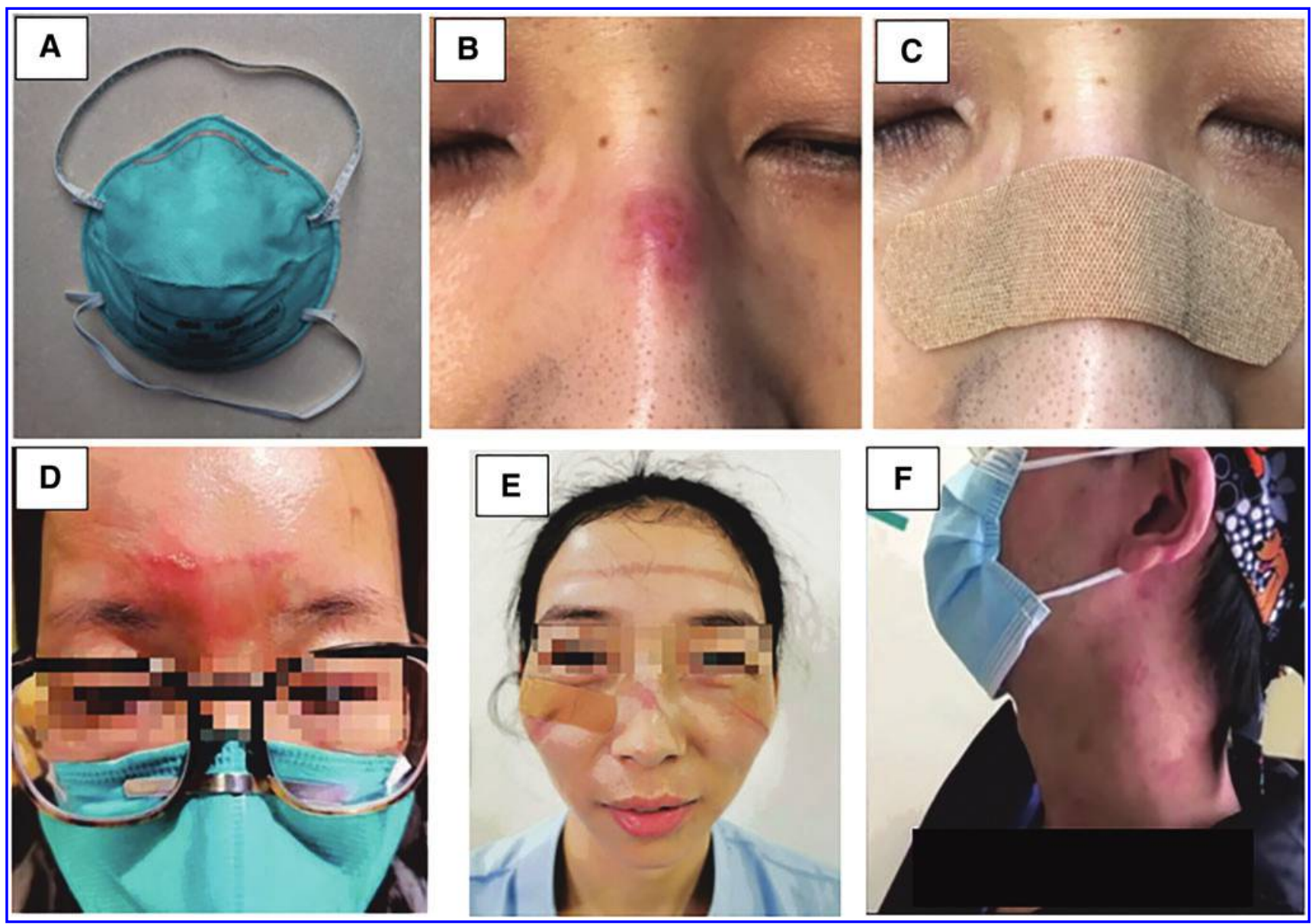

Figure 9. Examples of personal protective equipment-induced pressure ulcers seen during the COVID-19 pandemic. (A) Example of N95 respirator mask used by health care professionals. (B) Pressure sore, caused by an N95 mask, located on the nasal bridge. (C) Possible preventable method includes the application of benzalkonium chloride bridge before wearing mask. (D) Device-related pressure injury present on forehead of medical staff member fighting COVID-19 in China. (E) Device-related pressure injuries and impressions on face of health care personnel. (F) Device-related pressure injury located on the neck. Reproduced with permission from John Wiley and sons (A-C); Mary Ann Liebert, Inc. (D-F). The following original reports are credited: Yin ${ }^{91}$; Jiang et al. ${ }^{83}$

N95 respirators, goggles, and protective masks. PPE-induced DRPU in medical staff had an overall prevalence of $30.03 \%$, the highest among PPEinduced skin injuries. For context, a systematic review conducted in 2019 estimated the pooled prevalence of non-PPE-acquired DRPU in adult patients to be only $11 \%$, a number significantly lower compared to DRPU in medical personnel during COVID-19. ${ }^{89}$ The majority of PPE-induced DRPU were located on the nasal bridge and cheeks (59.65\%); lesser known locations included the auricle, forehead, zygoma, mandible, and eyebrow arch. ${ }^{87}$ Non-PPE-acquired DRPU locations included head, face, ears, feet, neck, sacrum, and buttocks. ${ }^{89}$ Around $98.84 \%$ of DRPU reported in the medical staff belonged to Stage 1 and Stage 2 of pressure ulcer categories. Risk factors for PPEinduced DRPU were similar to those seen in overall PPE-induced skin injuries; however, age was excluded as a significant risk factor. ${ }^{87}$
As mentioned earlier, the PPE primarily responsible for DRPU among the medical staff in China included N95 respirators, goggles, and protective masks. ${ }^{87}$ Etiology of PPE-induced DRPUs is thought to be very similar to etiology of DRPUs from continuous positive airway pressure masks, used for sleep apnea. The proposed mechanism triggering pressure ulcers begins with prolonged use of medical face masks and protective goggles, resulting in facial skin indentation or damage. Movement of facial muscles can inflict frictional damage of the skin caused by tightening of PPE straps and continuous movement of PPE over the skin. This frictional damage can be increased by perspiration of the medical personnel, eventually leading to the shearing of skin and subdermal tissues. In addition, the skin's tolerance to mechanical stress is weakened by increasing humidity at the PPE-skin boundary. As a consequence of these two unfavorable effects to the skin, tissue and cell 
deformation can occur, potentially leading to cell death if the deformation is sustained. Cell death can initiate a damaging cycle of DRPU involving inflammation, edema, interstitial pressure, ischemia, and tissue death. ${ }^{86}$ However, this cycle is an unlikely outcome for PPE-induced DRPU due to health care personnel being able to respond when they sense any uncomfortable feeling. ${ }^{86}$

\section{Treatment and management for PPE-induced pressure ulcers}

Treatment strategies vary among studies due to the low number of cases reported. Lam et al. reported a case series of five health care workers presenting with nasal bridge pressure ulcers associated with N95 respirators. ${ }^{88}$ In all cases, the N95 respirator remained on for an average of $5 \mathrm{~h}$ each time the mask was applied. Four of these cases were categorized as grade 1 pressure ulcers and treated with Duoderm Extra Thin dressings (hydrocolloid dressings), while one case was categorized as a grade 3 pressure ulcer and treated with BETAplast. ${ }^{88}$ Thin hydrocolloid dressing was also used as treatment in a case report of a nurse presenting with a grade 2 pressure ulcer on the nasal bridge. This case was also associated with an N95 respirator mask. ${ }^{90}$ One study proposed an improved treatment option for health care personnel involving the addition of a benzalkonium chloride patch to the pressure ulcer before using hydrocolloid dressing and applying the N95 mask. Reasoning behind this method included protection of the existing pressure ulcer, while preventing additional severity of the ulcer when the patch was removed. ${ }^{91}$

Other treatment recommendations for PPEinduced ulcers included wet dressing to promote wound convergence, silver ion dressings to prevent infection and secondary damage by frequent dressing replacements, and epidermal growth factor/fibroblast growth factor to stimulate cell proliferation and expedite wound healing. ${ }^{82}$

Possible complications arising from PPEinduced ulcers could involve an introduction to new infections and a breach of PPE protocol leading to increased contamination. Interestingly, the introduction of viral infections other than COVID-19 or bacterial infections could lead to cutaneous manifestations of their own, mimicking those associated with COVID-19. Due to these complications, prevention of PPE-induced pressure ulcers is paramount. One of the preventative methods discussed include proper PPE training; this could reinforce the proper use of an N95 respirator and discuss problems associated with ex-
Innovation: COVID-19 is an emergent disease, of which there is a clear void in understanding. Current actions are based on scientific information as they emerge. Comprehensive understanding of COVID-19 requires critical examination of all manifestations as evident in patients. A growing body of scientific evidence points toward consistent skin pathologies in COVID-19-affected patients. This article offers a critical review of the current literature on COVID-19 cutaneous manifestations. It also addresses the risk of PPE-associated ulcer in health care providers managing COVID-19.

tremely tight N95 mask securement. ${ }^{88}$ Other preventative measures include the relief of pressure buildup in N95 masks every $2 \mathrm{~h}$ and the addition of prophylactic barrier creams at least 30 min before applying the respirator mask. ${ }^{88} \mathrm{Fi}$ nally, wearing a properly fitted mask, correct goggle use, the application of moistures/gels, and management of skin indentations could help protect one from a pressure injury. ${ }^{31}$

There are few limitations of this systematic review. One of them being the large number of suspected, but unverified COVID-19 patients due to lack of testing or faulty tests. Also, studies over the dermatologic side effects of medications are absent. In addition, statistical analysis of the results is lacking due to the vast heterogeneity of cutaneous manifestations, rash onset, duration, and associated symptoms. The primary literature articles included in this study were mainly from France, Spain, Italy, and the United Kingdom. Because a majority of articles originate from Europe, this can present with its own limitations in providing a diverse population/methodology. Finally, some literature reviews concerning the cutaneous manifestations were unable to be translated to English; this may have also interfered with data collection. Careful documentation and examination by physicians experienced with cutaneous manifestations are needed for improved understanding of rashes, treatments, and pathophysiological mechanisms.

\section{MANAGEMENT CONSIDERATIONS OF CUTANEOUS MANIFESTATIONS OF COVID-19}

As the number of articles written about COVID19's cutaneous manifestations increase daily, the same cannot be said for possible treatments options. During primary literature review, most 
articles were geared toward the classification, histology, and descriptions of the cutaneous manifestations as well as explanations of possible etiologies. Many reports, including Galvin et al., reported the use of proposed medications for the treatment of COVID-19 itself: hydroxychloroquine, NSAIDs, lopinavir/ritonavir, tocilizumab, azithromycin, and systemic corticosteroids. ${ }^{11}$ As mentioned, these treatment options were not used for the rash, but many did note skinassociated side effects. For example, Sharma et al. reported common adverse reactions of pruritus, urticaria, and erythema multiforme with the use of hydroxychloroquine. $^{92}$ Some of these adverse cutaneous manifestations fall within the abovementioned COVID-19 skin manifestations. However, most of the discussed cutaneous manifestations of COVID-19 have been shown to be selfresolving. ${ }^{93}$ De Giorgi et al. reported spontaneous resolution of inflammatory cutaneous lesions, including vesicular, petechial, and maculopapular lesions. ${ }^{17}$ However, Reymundo et al. reported use of systemic corticosteroids in six of seven patients in the retrospective study looking into the presence of maculopapular rash. ${ }^{13}$ Cordoro et al. reported conservative care for patients with livedo-like lesions. ${ }^{55}$ Few studies also reported spontaneous resolution for chilblain lesions. ${ }^{37,39}$ Mastrolonardo et al. proposed the use of topical corticosteroids and antibiotics for chilblains, but only as a means to allow a faster recovery time otherwise the lesions can self-heal. ${ }^{94}$ In the review article by Algaadi, the author noted treatment for urticaria was challenging as there are many triggers that can lead to this type of rash from simple allergic reaction to viral to medication induced. In this review, treatment involved the use of antihistamines with or without steroid use. ${ }^{95}$ Majority of articles covering multisystem inflammatory syndrome (Kawashilike rash) reported use of IVIGs. ${ }^{65,68,69,96}$ The exact effects of these treatments on COVID-19 skin manifestations are unclear and need further investigation.

\section{SUMMARY}

In conclusion, knowledge of COVID-19 cutaneous manifestations may be vital to early diagnosis and lead to possible better prognosis in COVID-19 patients. This systematic review provides a detailed analysis of the primary skin complications associated with COVID-19 and their plausible underlying molecular mechanisms. Furthermore, the importance and pathogenesis of PPE-induced pressure ulcers are provided, in addition to their possible treatments. Further research concerning COVID-19's cutaneous manifestations is very much needed for a complete analysis of COVID-19.

\section{ACKNOWLEDGMENTS AND FUNDING SOURCES}

Work in the laboratory of Dr. Chandan K. Sen is funded by NIH grants GM069589, GM077185, GM108014, and NR013898. Research programs lead by Dr. Chandan K. Sen are also supported by the Lilly Endowment INCITE (Indiana Collaborative Initiative for Talent Enrichment) program. The research activities of Harjas Singh were supported by the Indiana Clinical and Translational Sciences Institute was funded, in part, by UL1TR002529 from the NIH.

\section{AUTHOR DISCLOSURE AND GHOSTWRITING}

No potential conflicts of interest relevant to this article were reported. No ghost writers were involved in the completion of this article.

\section{ABOUT THE AUTHORS}

Harjas Singh, BS, is a second-year medical student attending Indiana University School of Medicine. He received his undergraduate education at Indiana State University. His career interests include either surgery or anesthesiology. Harleen Kaur, MD, is an internal medicine resident physician at Indiana University School of 
Medicine. She is interested in pursuing either a pulmonary critical care or gastroenterology fellowship. Kanhaiya Singh, PhD, is an Assistant Professor at the Indiana Center for Regenerative Medicine and Engineering at the Indiana University School of Medicine. His laboratory currently focuses on molecular genetic approaches to investigate the pathways that are compromised in diabetic wound healing. Specific focus of his program is directed toward diabetes-inducible epige- netic mechanisms in the skin and wound. Chandan K. Sen, PhD, is a Distinguished Professor and J. Stanley Battersby Chair and Professor of Surgery at the Indiana University School of Medicine. He directs the Indiana University Health Comprehensive Wound Center. He serves as the PI of the Indiana-based Clinical Research Unit as well as of the TEWL Biomarker trial of the national Diabetic Foot Consortium sponsored by the NIDDK.

\section{REFERENCES}

1. Guo YR, Cao QD, Hong ZS, et al. The origin, transmission and clinical therapies on coronavirus disease 2019 (COVID-19) outbreak —an update on the status. Mil Med Res 2020;7:11.

2. Abouhashem AS, Singh K, Azzazy HME, Sen CK. Is low alveolar type II Cell SOD3 in the lungs of elderly linked to the observed severity of COVID-19? Antioxid Redox Signal 2020;33:59-65.

3. Li MY, Li L, Zhang Y, Wang XS. Expression of the SARS-CoV-2 cell receptor gene ACE2 in a wide variety of human tissues. Infect Dis Poverty 2020; 9:45

4. Xue X, Mi Z, Wang Z, Pang Z, Liu H, Zhang F. High expression of ACE2 on keratinocytes reveals skin as a potential target for SARS-CoV-2. J Invest Dermatol 2020 [Epub ahead of print]; DOl: 10.1016/j.jid.2020.05.087.

5. Recalcati S. Cutaneous manifestations in COVID-19: a first perspective. J Eur Acad Dermatol Venereol 2020;34:e212-e213.

6. Guan WJ, Ni ZY, Hu Y, et al. Clinical characteristics of coronavirus disease 2019 in China. N Engl J Med 2020;382:1708-1720.

7. Klejtman T. Skin and COVID-19. J Med Vasc 2020; 45:175-176.

8. Ortega-Quijano D, Jimenez-Cauhe J, SeldaEnriquez G, Fernandez-Guarino M, FernandezNieto D. Algorithm for the classification of COVID-19 rashes. J Am Acad Dermatol 2020;83 e103-e104.

9. Ely JW, Seabury Stone M. The generalized rash: part I. Differential diagnosis. Am Fam Physician 2010;81:726-734.

10. Ely JW, Seabury Stone M. The generalized rash: part II. Diagnostic approach. Am Fam Physician 2010;81:735-739

11. Galván Casas C, Català A, Carretero Hernández G, et al. Classification of the cutaneous manifestations of COVID-19: a rapid prospective nationwide consensus study in Spain with 375 cases. $\mathrm{Br} \mathrm{J}$ Dermatol 2020;183:71-77.
12. Herrero-Moyano M, Capusan TM, AndreuBarasoain $\mathrm{M}$, et al. A clinicopathological study of eight patients with COVID-19 pneumonia and a late-onset exanthema. J Eur Acad Dermatol Venereol 2020 [Epub ahead of print]; DOI: 10.1111/ jdv. 16631.

13. Reymundo A, Fernáldez-Bernáldez A, Reolid A, et al. Clinical and histological characterization of late appearance maculopapular eruptions in association with the coronavirus disease 2019. A case series of seven patients. J Eur Acad Dermatol Venereol 2020 [Epub ahead of print]; DOI: $10.1111 / j d v .16707$.

14. Rubio-Muniz CA, Puerta-Peña M, FalkenhainLópez D, et al. The broad spectrum of dermatological manifestations in COVID-19: clinical and histopathological features learned from a series of 34 cases. J Eur Acad Dermatol Venereol 2020 [Epub ahead of print]; DOI: 10.1111/jdv.16734.

15. de Masson A, Bouaziz JD, Sulimovic L, et al. Chilblains is a common cutaneous finding during the COVID-19 pandemic: a retrospective nationwide study from France. $\mathrm{J} \mathrm{Am} \mathrm{Acad} \mathrm{Dermatol}$ 2020:83:667-670

16. Askin 0, Altunkalem RN, Altinisik DD, Uzuncakmak TK, Tursen U, Kutlubay Z. Cutaneous manifestations in hospitalized patients diagnosed as COVID19. Dermatol Ther 2020 [Epub ahead of print]; DOI: $10.1111 /$ dth. 13896

17. De Giorgi V, Recalcati S, Jia Z, et al. Cutaneous manifestations related to coronavirus disease 2019 (COVID-19): a prospective study from China and Italy. J Am Acad Dermatol 2020;83:674-675.

18. Gianotti R, Recalcati S, Fantini F, et al. Histopathological study of a broad spectrum of skin dermatoses in patients affected or highly suspected of infection by COVID-19 in the northern part of Italy: analysis of the many faces of the viral-induced skin diseases in previous and new reported cases. Am J Dermatopathol 2020;42: 564-570.

19. Bursal Duramaz B, Yozgat CY, Yozgat $Y$, Turel 0. Appearance of skin rash in pediatric patients with
COVID-19: three case presentations. Dermato Ther 2020:e13594.

20. Tursen U, Tursen B, Lotti T. Cutaneous sideeffects of the potential COVID-19 drugs. Dermatol Ther 2020:e13476.

21. Diotallevi F, Campanati A, Bianchelli T, et al. Skin involvement in SARS-CoV-2 infection: case series. $J$ Med Virol 2020 [Epub ahead of print]; DOI: 10.1002/jmv.26012.

22. Radonjic-Hoesli $S$, Hofmeier KS, Micaletto $S$, Schmid-Grendelmeier $P$, Bircher A, Simon D. Urticaria and angioedema: an update on classification and pathogenesis. Clin Rev Allergy Immunol 2018:54:88-101.

23. van Damme C, Berlingin E, Saussez S, Accaputo 0 . Acute urticaria with pyrexia as the first manifestations of a COVID-19 infection. J Eur Acad Dermatol Venereol 2020;34:e300-e301.

24. Najafzadeh M, Shahzad F, Ghaderi N, Ansari K, Jacob B, Wright A. Urticaria (angioedema) and COVID-19 infection. J Eur Acad Dermatol Venereol 2020 [Epub ahead of print]; DOI: 10.1111/ jdv.16721.

25. Cabrera-Hernandez R, Solano-Solares E, ChicaGuzman V, et al. SARS-CoV-2, skin lesions and the need of a multidisciplinary approach. J Eur Acad Dermatol Venereol 2020 [Epub ahead of print] DOI: 10.1111/jdv.16745.

26. Hassan K. Urticaria and angioedema as a prodromal cutaneous manifestation of SARS-CoV-2 (COVID-19) infection. BMJ Case Rep 2020;13: e236981.

27. Dalal A, Jakhar D, Agarwal V, Beniwal R. Dermatological findings in SARS-CoV-2 positive patients: an observational study from North India. Dermatol Ther 2020:e13849

28. Henry D, Ackerman M, Sancelme E, Finon A, Esteve E. Urticarial eruption in COVID-19 infection. J Eur Acad Dermatol Venereol 2020;34:e244-e245.

29. Fernandez-Nieto $D$, Ortega-Quijano D, SeguradoMiravalles G, Pindado-Ortega C, Prieto-Barrios M, 
Jimenez-Cauhe J. Comment on: Cutaneous manifestations in COVID-19: a first perspective. Safety concerns of clinical images and skin biopsies.

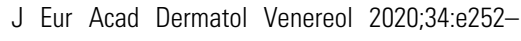
e254.

30. Criado PR, Abdalla BMZ, de Assis IC, van Blarcum de Graaff Mello C, Caputo GC, Vieira IC. Are the cutaneous manifestations during or due to SARSCoV-2 infection/COVID-19 frequent or not? Revision of possible pathophysiologic mechanisms. Inflamm Res 2020;69:745-756.

31. Yan $Y$, Chen $H$, Chen $L$, et al. Consensus of Chinese experts on protection of skin and mucous membrane barrier for health-care workers fighting against coronavirus disease 2019. Dermatol Ther 2020:e13310.

32. Cappel JA, Wetter DA. Clinical characteristics, etiologic associations, laboratory findings, treatment, and proposal of diagnostic criteria of pernio (chilblains) in a series of 104 patients at Mayo Clinic, 2000 to 2011. Mayo Clin Proc 2014;89:207215.

33. Hughes M, Herrick AL. Raynaud's phenomenon. Best Pract Res Clin Rheumatol 2016;30:112-132.

34. Freeman EE, McMahon DE, Lipoff JB, et al. Pernio-like skin lesions associated with COVID-19: a case series of 318 patients from 8 countries. J Am Acad Dermatol 2020;83:486-492.

35. Docampo-Simón A， Sánchez-Pujol MJ, JuanCarpena G, et al. Are chilblain-like acral skin lesions really indicative of COVID-19? A prospective study and literature review. J Eur Acad Dermatol Venereol 2020 [Epub ahead of print]; DOI: $10.1111 /$ jdv. 16665

36. Duong TA, Velter C, Rybojad M, et al. Did Whatsapp((R)) reveal a new cutaneous COVID-19 manifestation? J Eur Acad Dermatol Venereol 2020;34:e348-e350.

37. Andina D, Noguera-Morel L, Bascuas-Arribas M, et al. Chilblains in children in the setting of COVID-19 pandemic. Pediatr Dermatol 2020;37: 406-411.

38. Colonna C, Genovese G, Monzani NA, et al. Outbreak of chilblain-like acral lesions in children in the metropolitan area of Milan, Italy, during the COVID-19 pandemic. J Am Acad Dermatol 2020; 83:965-969.

39. El Hachem M, Diociaiuti A, Concato C, et al. A clinical, histopathological and laboratory study of 19 consecutive Italian paediatric patients with chilblain-like lesions: lights and shadows on the relationship with COVID-19 infection. J Eur Acad Dermatol Venereol 2020 [Epub ahead of print]; DOI: 10.1111/jdv.16682.

40. Fernandez-Nieto D, Jimenez-Cauhe J, SuarezValle $A$, et al. Characterization of acute acral skin lesions in nonhospitalized patients: a case series of 132 patients during the COVID-19 outbreak. $\mathrm{J}$ Am Acad Dermatol 2020;83:e61-e63.

41. Garcia-Lara G, Linares-González L， RódenasHerranz T, Ruiz-Villaverde R. Chilblain-like lesions in pediatrics dermatological outpatients during the COVID-19 outbreak. Dermatol Ther 2020: e13516.

42. Gaspari V, Neri I, Misciali C, Patrizi A. COVID-19: how it can look on the skin. Clinical and pathological features in 20 COVID-19 patients observed in Bologna, north-eastern Italy. J Eur Acad Dermatol Venereol 2020 [Epub ahead of print]; DOI: 10.1111/jdv.16693.

43. Wollina U, Karadag AS, Rowland-Payne C, Chiriac A, Lotti T. Cutaneous signs in COVID-19 patients: a review. Dermatol Ther 2020:e13549.

44. Bouaziz JD, Duong $T$, Jachiet $M$, et al. Vascular skin symptoms in COVID-19: a french observational study. J Eur Acad Dermatol Venereol 2020 [Epub ahead of print]; DOI: 10.1111/jdv .16544.

45. Caselli D, Chironna M, Loconsole D, et al. No evidence of SARS-Cov-2 infection by PCR or serology in children with pseudochilblain. $\mathrm{Br} \mathrm{J}$ Dermatol 2020 [Epub ahead of print]; DOI: 10.1111/bjd.19349.

46. Le Cleach L, Dousset L, Assier H, et al. Most chilblains observed during the COVID-19 outbreak occur in patients who are negative for COVID-19 on PCR and serology testing. Br J Dermatol 2020 [Epub ahead of print]; DOI: 10.1111/bjd.19377.

47. Drago F, Ciccarese G, Gasparini G, et al. Contemporary infectious exanthems: an update. Future Microbiol 2017;12:171-193.

48. Fernandez-Nieto D, Ortega-Quijano D, JimenezCauhe J, et al. Clinical and histological characterization of vesicular COVID-19 rashes: a prospective study in a tertiary care hospital. Clin Exp Dermatol 2020 [Epub ahead of print]; DOI: 10.1111/ced.14277.

49. Marzano AV, Genovese G, Fabbrocini G, et al. Varicella-like exanthem as a specific COVID-19associated skin manifestation: multicenter case series of 22 patients. $\mathrm{J} \mathrm{Am} \mathrm{Acad} \mathrm{Dermatol} \mathrm{2020;}$ 83:280-285

50. Marzano AV, Cassano N, Genovese G, Moltrasio C, Vena GA. Cutaneous manifestations in patients with COVID-19: a preliminary review of an emerging issue. Br J Dermatol 2020;183:431-442.

51. McGrath A, Barrett MJ. Petechiae. Treasure Island, FL: StatPearls, 2020.

52. Caputo V, Schroeder J, Rongioletti F. A generalized purpuric eruption with histopathologic features of leucocytoclastic vasculitis in a patient severely ill with COVID-19. J Eur Acad Dermatol Venereol 2020 [Epub ahead of print]; DOI: 10.1111/jdv.16737.

53. Magro C, Mulvey JJ, Berlin D, et al. Complement associated microvascular injury and thrombosis in the pathogenesis of severe COVID-19 infection: a report of five cases. Transl Res 2020;220:1-13.

54. Sajjan VV, Lunge S, Swamy MB, Pandit AM. Livedo reticularis: a review of the literature. Indian Dermatol Online J 2015;6:315-321.

55. Cordoro KM, Reynolds SD, Wattier R, McCalmont TH. Clustered cases of acral perniosis: clinical features, histopathology, and relationship to COVID-19. Pediatr Dermatol 2020;37:419-423.

56. Tang N, Li D, Wang X, Sun Z. Abnormal coagulation parameters are associated with poor prognosis in patients with novel coronavirus pneumonia. J Thromb Haemost 2020;18:844-847.

57. Manalo IF, Smith MK, Cheeley J, Jacobs R. Reply to: "Reply: a dermatologic manifestation of COVID-19: transient livedo reticularis". J Am Acad Dermatol 2020;83:e157.

58. Galeotti C, Bayry J. Autoimmune and inflammatory diseases following COVID-19. Nat Rev Rheumatol 2020;16:413-414.

59. Verdoni L, Mazza A, Gervasoni A, et al. An outbreak of severe Kawasaki-like disease at the Italian epicentre of the SARS-CoV-2 epidemic: an observational cohort study. Lancet 2020;395: 1771-1778.

60. Ebina-Shibuya R, Namkoong H, Shibuya Y, Horita N. Multisystem inflammatory syndrome in children (MIS-C) with COVID-19: insights from simultaneous familial Kawasaki Disease cases. Int J Infect Dis 2020;97:371-373.

61. Panupattanapong $S$, Brooks EB. New spectrum of COVID-19 manifestations in children: kawasakilike syndrome and hyperinflammatory response. Cleve Clin J Med 2020 [Epub ahead of print]; DOI: 10.3949/ccjm.87a.ccc039.

62. Whittaker E, Bamford A, Kenny J, et al. Clinical characteristics of 58 children with a pediatric inflammatory multisystem syndrome temporally associated with SARS-CoV-2. JAMA 2020;324: 259-269.

63. Miller J, Cantor A, Zachariah P, Ahn D, Martinez M, Margolis K. Gastrointestinal symptoms as a major presentation component of a novel multisystem inflammatory syndrome in children (MIS-C) that is related to COVID-19: a single center experience of 44 cases. Gastroenterology 2020 [Epub ahead of print]; DOI: 10.1053/j.gastro .2020.05.079.

64. Hameed S, Elbaaly H, Reid CEL, et al. Spectrum of imaging findings on chest radiographs, US, CT, and MRI images in multisystem inflammatory syndrome in children (MIS-C) associated with COVID-19. Radiology 2020:202543.

65. Belhadjer Z, Méot M, Bajolle F, et al. Acute heart failure in multisystem inflammatory syndrome in children (MIS-C) in the context of global SARSCoV-2 pandemic. Circulation 2020 [Epub ahead of print]; DOI: 10.1161/CIRCULATIONAHA.120 .048360 .

66. Toubiana J, Poirault C, Corsia A, et al. Kawasakilike multisystem inflammatory syndrome in children during the covid-19 pandemic in Paris, France: prospective observational study. BMJ 2020;369:m2094.

67. Pouletty M, Borocco C, Ouldali N, et al. Paediatric multisystem inflammatory syndrome temporally associated with SARS-CoV-2 mimicking Kawasaki disease (Kawa-COVID-19): a multicentre cohort. Ann Rheum Dis 2020;79:999-1006. 
68. Grimaud M, Starck J, Levy M, et al. Acute myocarditis and multisystem inflammatory emerging disease following SARS-CoV-2 infection in critically ill children. Ann Intensive Care 2020;10:69.

69. Cheung EW, Zachariah P, Gorelik $M$, et al. multisystem inflammatory syndrome related to COVID-19 in previously healthy children and adolescents in New York City. JAMA 2020;324: 294-296.

70. Riollano-Cruz M, Akkoyun E, Briceno-Brito E, et al Multisystem inflammatory syndrome in children (MIS-C) related to COVID-19: a New York City experience. J Med Virol 2020 [Epub ahead of print]; DOI: 10.1002/jmv.26224.

71. Kaushik S, Aydin SI, Derespina KR, et al. Multisystem inflammatory syndrome in children (MIS-C) associated with SARS-CoV-2 infection: a multiinstitutional study from New York City. J Pediatr 2020;224:24-29.

72. Yozgat CY, Uzuner S, Bursal Duramaz B, et al. Dermatological manifestation of pediatrics multisystem inflammatory syndrome associated with COVID-19 in a 3-year-old girl. Dermatol Ther 2020: e13770

73. Bahrami A, Vafapour M, Moazzami B, Rezaei N. Hyperinflammatory shock related to COVID-19 in a patient presenting with multisystem inflammatory syndrome in children: first case from Iran. J Paediatr Child Health 2020 [Epub ahead of print]; DOI: 10.1111/jpc.15048.

74. McCrindle BW, Manlhiot C. SARS-CoV-2-related inflammatory multisystem syndrome in children: different or shared etiology and pathophysiology as Kawasaki Disease? JAMA 2020;324:246-248.

75. Rongioletti F. SARS-CoV, Mers-CoV and COVID-19: what differences from a dermatological viewpoint? J Eur Acad Dermatol Venereol 2020 [Epub ahead of print]; DOI: 10.1111/jdv.16738.

76. Skowronski DM, Chambers C, Osei W, et al. Case series of rash associated with influenza $B$ in school children. Influenza Other Respir Viruses 2015;9:32-37.

77. Arnold JC, Singh KK, Spector SA, Sawyer MH Human bocavirus: prevalence and clinical spectrum at a children's hospital. Clin Infect Dis 2006 43:283-288.

78. Garcia-Garcia ML, Calvo Rey C, Pozo Sanchez F, et al. [Human bocavirus infections in Spanish 0 14 year-old: clinical and epidemiological characteristics of an emerging respiratory virus]. An Pediatr (Barc). 2007;67:212-219.

79. Korman AM, Alikhan A, Kaffenberger BH. Viral exanthems: an update on laboratory testing of the adult patient. J Am Acad Dermatol 2017;76:538-550
80. Wang SM, Liu CC, Wang HC, Su IJ, Wang JR. Human metapneumovirus infection among children in Taiwan: a comparison of clinical manifestations with other virus-associated respiratory tract infections. Clin Microbiol Infect 2006;12:1221-1224.

81. Cherry JD. Contemporary infectious exanthems. Clin Infect Dis 1993;16:199-205.

82. Zhou N-Y, Yang L, Dong L-Y, et al. Prevention and treatment of skin damage caused by personal protective equipment: experience of the first-line clinicians treating 2019-nCoV infection. Int J Dermatol Venereol [Epub ahead of print]; DOI: 10.1097/JD9.0000000000000085.

83. Jiang $\mathrm{Q}$, Song S, Zhou J, et al. The prevalence, characteristics, and prevention status of skin injury caused by personal protective equipment among medical staff in fighting COVID-19: a multicenter, cross-sectional study. Adv Wound Care (New Rochelle) 2020;9:357-364.

84. Gefen A, Ousey K. Prevention of skin damage caused by the protective equipment used to mitigate COVID-19. J Wound Care 2020;29:311.

85. Hu K, Fan J, Li X, Gou X, Li X, Zhou X. The adverse skin reactions of health care workers using personal protective equipment for COVID-19. Medicine (Baltimore) 2020;99:e20603

86. Gefen A, Ousey K. Update to device-related pressure ulcers: SECURE prevention. COVID-19, face masks and skin damage. J Wound Care 2020; 29:245-259.

87. Jiang Q, Liu $Y$, Wei $W$, et al. The prevalence, characteristics, and related factors of pressure injury in medical staff wearing personal protective equipment against COVID-19 in China: a multicentre cross-sectional survey. Int Wound J 2020 [Epub ahead of print]; DOI: 10.1111/iwj.13391.

88. Lam UN, Md Mydin Siddik NSF, Mohd Yussof SJ, Ibrahim S. N95 respirator associated pressure ulcer amongst COVID-19 health care workers. Int Wound J 2020 [Epub ahead of print]; DOI: 10.1111/iwj.13398.

89. Jackson D, Sarki AM, Betteridge R, Brooke J. Medical device-related pressure ulcers: a systematic review and meta-analysis. Int J Nurs Stud 2019:92:109-120.

90. Sernicola A, Chello C, Cerbelli E, et al. Treatment of nasal bridge ulceration related to protective measures for the COVID-19 epidemic. Int Wound J 2020 [Epub ahead of print]; DOI: 10.1111/iwj.13397.

91. Yin Z0. Covid-19: countermeasure for N95 maskinduced pressure sore. J Eur Acad Dermatol Venereol 2020;34:e294-e295.

92. Sharma AN, Mesinkovska NA, Paravar T. Characterizing the adverse dermatologic effects of hydroxychloroquine: a systematic review. J Am Acad Dermatol 2020;83:563-578.

93. Gupta A, Madhavan MV, Sehgal K, et al. Extrapulmonary manifestations of COVID-19. Nat Med 2020;26:1017-1032

94. Mastrolonardo M, Romita P, Bonifazi E, et al. The management of the outbreak of acral skin manifestations in asymptomatic children during COVID-19 era. Dermatol Ther 2020:e13617.

95. Algaadi SA. Urticaria and COVID-19: a review. Dermatol Ther 2020:e14290.

96. Ahmed M, Advani S, Moreira A, et al. Multisystem inflammatory syndrome in children: a systematic review. EClinicalMedicine 2020:100527.

97. Gottlieb M, Long B. Dermatologic manifestations and complications of COVID-19. Am J Emerg Med 2020:38:1715-1721.

\section{Abbreviations and Acronyms}

ACE2 = angiotensin-converting enzyme 2 $\mathrm{CDC}=$ Centers for Disease Control and Prevention

COVID-19 $=$ Coronavirus Disease 2019

$\mathrm{DIC}=$ disseminated intravascular coagulation

DRPU $=$ device-related pressure ulcer

H\&E stain $=$ hematoxylin and eosin stain

HFMD $=$ hand-foot-mouth disease

$\lg \mathrm{A}=$ immunoglobulin $\mathrm{A}$

$\lg \mathrm{G}=$ immunoglobulin $\mathrm{G}$

$\lg \mathrm{M}=$ immunoglobulin $\mathrm{M}$

$\mathrm{IQR}=$ interquartile range

IVIG = intravenous immunoglobulin

$\mathrm{LR}=$ livedo reticularis

$\mathrm{LRC}=$ livedo racemosa

MERS-CoV $=$ Middle East respiratory syndrome coronavirus

MIS-C = multisystem inflammatory syndrome in children

$\mathrm{N} / \mathrm{A}=$ not available

NPIAP $=$ National Pressure Injury Advisory Panel

$\mathrm{NR}=$ not reported

NSAIDs $=$ nonsteroidal anti-inflammatory drugs

PPE $=$ personal protective equipment

PRISMA $=$ Preferred Reporting Items for Systematic Reviews and Meta-Analyses

$\mathrm{RSV}=$ respiratory syncytial virus

RT-PCR $=$ reverse transcription polymerase chain reaction

SARS-CoV $=$ severe acute respiratory syndrome coronavirus

SARS-CoV-2 $=$ severe acute respiratory syndrome coronavirus 2 


\section{This article has been cited by:}

1. Prashanth R. J. Vas, George S. Georgiadis, Nikolaos Papanas. 2021. COVID-19 Toes and Other Skin Lesions During the Pandemic: Emerging Entities?. The International Journal of Lower Extremity Wounds 5, 153473462110118. [Crossref]

2. Alfonso Papa, Anna Maria Salzano, Maria Teresa Di Dato, Giuliano Lo Bianco, Mariangela Tedesco, Antonio Salzano, Dariusz Myrcik, Farnad Imani, Giustino Varrassi, Ghodrat Akhavan Akbari, Antonella Paladini. 2021. COVID-19 Related Acro-Ischemic Neuropathic-like Painful Lesions in Pediatric Patients: A Case Seriese. Anesthesiology and Pain Medicine In Press:In Press. . [Crossref]

3. Gurinder Kumar, Shanta Pillai, Paige Norwick, Hulya Bukulmez. 2021. Leucocytoclastic vasculitis secondary to COVID-19 infection in a young child. BMJ Case Reports 14:4, e242192. [Crossref]

4. Azize Pınar Metbulut, Aslınur Özkaya Parlakay, Gülsüm İclal Bayhan, Saliha Kanık Yüksek, Belgin Gülhan, Zeynep Şengül Emeksiz, Emrah Şenel, Emine Dibek Misırlıŏlu. 2021. Evaluation of cutaneous symptoms in children infected with COVID19. Pediatric Allergy and Immunology 34. . [Crossref]

5. Dominik Samotij, Ewelina Gawron, Justyna Szczęch, Elżbieta Ostańska, Adam Reich. 2021. Acrodermatitis Continua of Hallopeau Evolving into Generalized Pustular Psoriasis Following COVID-19: A Case Report of a Successful Treatment with Infliximab in Combination with Acitretin. Biologics: Targets and Therapy Volume 15, 107-113. [Crossref]

6. Laura Atzori, Sebastiano Recalcati, Caterina Ferreli, Leonard Hoenig, Franco Rongioletti. 2020. COVID-19-related skin manifestations: Update on therapy. Clinics in Dermatology . [Crossref] 